
SWPS 2015-26 (September)

The Rise of Mission-Oriented State Investment Banks: The Cases of Germany's KfW and Brazil's BNDES

Mariana Mazzucato

Caetano C.R. Penna

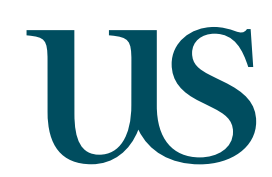

University of Sussex 


\section{SPRU Working Paper Series (ISSN 2057-6668)}

The SPRU Working Paper Series aims to accelerate the public availability of the research undertaken by SPRU-associated people of all categories, and exceptionally, other research that is of considerable interest within SPRU. It pres ents research results that in whole or part are suitable for submission to a refereed journal, to a sponsor, to a major confer ence or to the editor of a book. Our intention is to provide access to early copies of SPRU research.

\section{Editors}

Tommaso Ciarli

Daniele Rotolo

Associate Editors

Florian Kern

Paul Nightingale,

Ben Martin, \&

Ohid Yaqub

Matias Ramirez

Joe Tidd \&

Carlos Sato

Maria Savona \&

Mariana Mazzucato

Andrew Stirling

Caitriona McLeish
Area

Energy

Science, \& Technology Policy

Contact

T.Ciarli@sussex.ac.uk

D.Rotolo@sussex.ac.uk

F.Kern@sussex.ac.uk
P.Nightingale@sussex.ac.uk

B.Martin@sussex.ac.uk

O.Yaqub@sussex.ac.uk

Matias.Ramirez@sussex.ac.uk

J.Tidd@sussex.ac.uk

C.E.Y.Sato@sussex.ac.uk

Management

Economics of Technological Change

M.Savona@sussex.ac.uk

M.Mazzucato@sussex.ac.uk

A.C.Stirling@sussex.ac.uk

C.A.McLeish@sussex.ac.uk

\section{Disclaimer}

The works available here are the responsibility of the individual author(s) and do not necess arily repres ent the views of other SPRU researchers. As matters of policy and practice, SPRU does not endorse individual research contributions.

\section{Guidelines for authors}

Papers shall be submitted in pdf or Word format. They should contain a title, an abstract, and keywords. Papers should be submitted to one of the Editors, who will process them and send them to the appropriate Associate Editor. Two members of SPRU will be asked to provide a short written review within three weeks. The revised versions of the paper, together with a reply to the reviewers, should be sent to the Associate Editor, who will propose to the Editors its publication on the series. When submitting the authors should indicate if the paper has already undergone peer-reviewing, in which case the Associate Editors may decide to skip internal review process.

\section{Websites}

SWPS: www.sussex.ac.uk/spru/research/swps

IDEAS: ideas.repec.org/s/sru/ssewps.html

Research Gate: www.researchgate.net/journal/2057-6668_SPRU_Working_Paper_Series 


\title{
The rise of mission-oriented state investment banks: the cases of Germany's KfW and Brazil's BNDES
}

\author{
Mariana Mazzucato \\ Science Policy Research Unit (SPRU), Univ. of Sussex, UK \\ Address: University of Sussex \\ Jubilee Building, Room 384 \\ Brighton, United Kindgom, BN1 9SL \\ Email:m.mazzucato@sussex.ac.uk \\ Phone: +44(0)1273-877943
}

\author{
Caetano C.R. Penna (corresponding author) \\ Institute of Economics, Federal University of Rio de Janeiro, Brazil, and SPRU, Univ. \\ of Sussex, UK \\ Address: UFRJ - Instituto de Economia \\ Campus da Praia Vermelha \\ Av. Pasteur, $n^{\circ} 250$, sala 110 , Urca \\ Rio de Janeiro - RJ, Brazil, 22290-902 \\ Email: caetano.penna@pped.ie.ufrj.br \\ Phone: +5521 96510-1210
}

\begin{abstract}
This paper focuses on the rise of state investment banks (SIBs) as lead funders of missionoriented innovation in various countries' agendas regarding smart (innovation-led) growth, and not just fixers of 'market failures'. The market failure justification for public finance fails to capture the active mission-oriented role that such banks are playing in shaping and creating markets, rather than just fixing them. In tackling innovation priorities and shaping new markets, these banks are developing new financial tools that also help to reform the financial system from within, addressing issues of short-termism and financialisation. This paper documents and analyses the roles of such banks, building on the Neo-Schumpeterian work on mission-oriented policies (that is, policies that aim to address societal issues or challenges). The paper presents a rich analytical description of mission-oriented investments in two of the leading SIBs: Brazil's BNDES and Germany's KfW. We discuss the directionality of the investments, the various tools used, and the lessons to be learned for evaluating these tools outside of a market failure framework.
\end{abstract}

Keywords: State investment banks, mission-oriented policy, societal challenges, public finance, financialisation, innovation

JEL codes: G20 (financial institutions and services: general); O16 (economic development: financial markets); O38 (technological change: government policy); L52 (industrial policy); P16 (capitalist systems: political economy)

Acknowledgements: We are grateful to two anonymous referees of the SPRU Working Paper Series (SWPS) for their comments and helpful suggestions. Mazzucato is also grateful for funding by the Ford Foundation and by the European Commission Horizon 2020 programme (ISIG). 


\section{Introduction}

Many countries and regions currently have policy objectives of promoting smart (that is, innovation-led) growth agendas that are framed around 'grand challenges', such as those related to climate change and the ageing crisis (European Commission, 2011). Accordingly, the need for long-term investments in the real economy to achieve these goals and address societal challenges is enormous. The real question, however, is where the finance will come from to fund such long-term strategies. This question is especially relevant in an era in which the financial sector has become increasingly short-termist (Haldane, 2011; Kay, 2012) and private companies have become increasingly financialised, focused on quarterly stock market performance (Dore, 2008).

The case of green energy technologies, which are crucial for tackling climate change, energy security, air pollution, and resource depletion, is paradigmatic. Out of the massive amount of funds managed by institutional investors - US $\$ 83$ trillion as of 2012 - only US $\$ 13$ billion ( 0.016 per cent of the total) was committed to renewable energy projects in the eight years between 2004 and 2012 (Kaminker et al., 2013). And at the same time, the large energy companies are the biggest repurchasers of their own stock, preferring to boost stock prices than to invest in renewable energy innovation (Lazonick, 2013). Therefore, it is clear that the issue is not one of a lack of finance (or 'credit crunch'), but what type of finance it is and where it goes. Innovation requires patient, long-term finance, not just any type of finance (Mazzucato, 2013b).

The present paper deals with the new roles that state investment banks (SIBs) ${ }^{1}$ play in financing smart (that is, innovation-led) growth, due to private finance retreating from funding the real economy (Haldane, 2011). The paper shows that as private finance has retreated, the need for SIBs to fill the gap has increased. A select number of such public banks are providing counter-cyclical investments and also directing those investments in specific directions, related to technological missions and grand societal challenges. The key contribution of the present paper is to introduce the mission-oriented framework to the analysis of such an active role of SIBs in financing grand challenges. We argue that while the traditional 'market failure' framework can explain some of the investments, it is harder for this framework to explain the extensive and deep investments that such banks are providing in high-risk areas along the entire innovation chain. We argue that a 'mission-oriented' approach (Foray et al. 2012) is particularly useful for documenting such investments and for evaluating them. On the normative side, we argue that, in light of the policy priorities of achieving smart growth and of reforming the financial system so that long-term investments receive priority over short-term speculative ones, SIBs represent an institutional model to help reform the financial system from within and to achieve smart innovation-led growth.

The remainder of the paper is organised as follows. Section 2 discusses the contemporary context in which the financial system is increasingly inwardly focused, concentrated on achieving speculative short-term profits to the detriment of risky and uncertain financing of long-term projects, and, concomitantly, the real economy itself became speculative and financialised. This trend is contrasted with the policy agenda of achieving smart, inclusive and sustainable growth through policies that also seek to address societal challenges. Section 3 presents the roles of SIBs in the economy, from counter-cyclical and capital development to venture capitalist and mission-oriented. The paper focuses on the third and fourth roles; therefore, section 4 reviews the mission-oriented literature in detail to show that it overlooked the role of SIBs in financing mission-oriented projects. Section 5 presents the methodology as it is applied to the empirical section 6, which documents the rise of SIBs as venture capitalists and mission-oriented investors. This section focuses on two of the world's leading SIBs: one from a developing country (the national development bank of Brazil,

\footnotetext{
${ }^{1}$ Throughout this paper, the terms state investment bank and development bank are used interchangeably.
} 
BNDES) and the other from an industrialised country (Germany's KfW). Our rich empirical analysis highlights a contemporary trend whereby countries, via SIBs, move toward placing public finance at the centre of the investment and innovation process in order to address contemporary challenges and fulfil their smart, sustainable and inclusive growth agendas. Section 7 reflects on our empirical findings and concludes that, given the characteristics of the new missions (or societal challenges), SIBs seem better positioned than centralised funding agencies to finance related projects, including innovation. The paper finishes with a proposal for areas for future research on mission-oriented SIBs.

\title{
2. Financialisation: Who will fund the capital development of the economy?
}

The works of many prominent economists, including Thorstein Veblen, John Maynard Keynes and Hyman Minsky, have long pointed to the fact that the character of specific financial structures is not inconsequential to the workings of the real economy and productive enterprises. For instance, Veblen (1904) distinguished between industrial and pecuniary motives and emphasised how the pursuit of pecuniary gains by business managers and investment bankers is often in stark opposition to technological (industrial) advances (Wray, 2012). Keynes also highlighted how 'speculative' finance is a threat to the workings of industrial enterprises:

\begin{abstract}
Speculators do no harm as bubbles on a steady stream of enterprise. But the position is serious when enterprise becomes the bubble on a whirlpool of speculation. When the capital development of a country becomes the byproduct of the activities of a casino, the job is likely to be ill done. The measure of success attained by Wall Street, regarded as an institution of which the proper social purpose is to direct new investment into the most profitable channels in terms of future yield, cannot be claimed as one of the outstanding triumphs of laissez-faire capitalism - which is not surprising, if I am right in thinking that the best brains of Wall Street have been in fact directed towards a different object. (Keynes, 2006 [1936], p. 142-143)
\end{abstract}

As Minsky (1992) put it, this 'dichotomy between enterprise and speculation draws attention to the financial structure as an essential element in the capital development process. In a successful capitalist economy the financial structure abets enterprise. When finance fosters speculation the performance of a capitalist economy falters' (p. 11). The key point is that capital development investments such as innovation and infrastructure require finance, but the type of finance received affects the types of investments made (O'Sullivan, 2004; Mazzucato, 2013b). Indeed, the type of financial structures in an economy (for example, the quantity and type of banks) is not inconsequential to the workings of the real economy and productive enterprises. Some financial structures are conducive to what Minsky calls the 'capital development' of the economy, which includes privately owned capital equipment, technologies, skills, and public infrastructure (Minsky, 1992). Yet, capital development is hampered when speculative finance targets low-risk, short-term gains through the trade of securities and other investments types that '[amount] to little more than pyramid schemes [i.e., Minsky's "Ponzi finance"]' (Wray, 2012, p. 310). This is the issue of 'inept' (wrong) investments, which contributes to a second type of issue - insufficiency of investments (Minsky, 1992) - whereby funds are diverted from financing innovation, creating a funding/financing gap. Together, these issues lead to underinvestment in capital development and may ultimately lead to financial and economic crises. The global financial crisis of 2007 is a case in point. Minsky referred to the laissez-faire financial architecture that was established in the 1980s as 'money manager capitalism', which he believed was inhibiting the 'capital development of the economy' because it led to speculation, shorttermism, volatility, uncertainty and financial instability (Minsky and Whalen, 1996; Papadimitriou and Wray, 1998). 
As private finance has retreated from financing the real economy, the real economy itself has also become increasingly financialised, with spending on areas such as share buybacks exceeding spending on long-run investments like human capital formation and R\&D (Lazonick, 2013). Such financialisation of capitalist economies - a process whose deleterious effects became evident during the most recent global financial crisis - puts reforming the financial system back on the top of the agenda, with the goal of creating a new financial system that funds the capital development of the economy. Despite numerous attempts and proposals to reform the financial system, the situation remains as before the crisis, with speculative finance still rewarded more than patient long-term finance (Kregel, 2012; Hensarling and McHenry, 2014).

The issue of inept investments is critical if we consider that many countries and regions have policy objectives of promoting the smart (innovation-led) growth agenda, framed around 'grand challenges' related to issues such as climate change and the ageing crisis (European Commission, 2011). Therefore, the need for long-term investments in the real economy to achieve these goals and address the societal challenges is urgent. A key question is where will this kind of long-term funding come from, given the trend whereby private finance retreats from funding the real economy (Haldane, 2011; Kay, 2012) and the real economy itself becomes increasingly financialised (Dore, 2008; Lazonick, 2013)? For instance, Figure 1 below shows the financialisation of the UK economy by illustrating the degree to which financial intermediation has outpaced the growth of the real economy in the UK (with the US experiencing a similar process; see discussion in Krippner, 2005)).

Figure 1: The financialisation of the UK economy

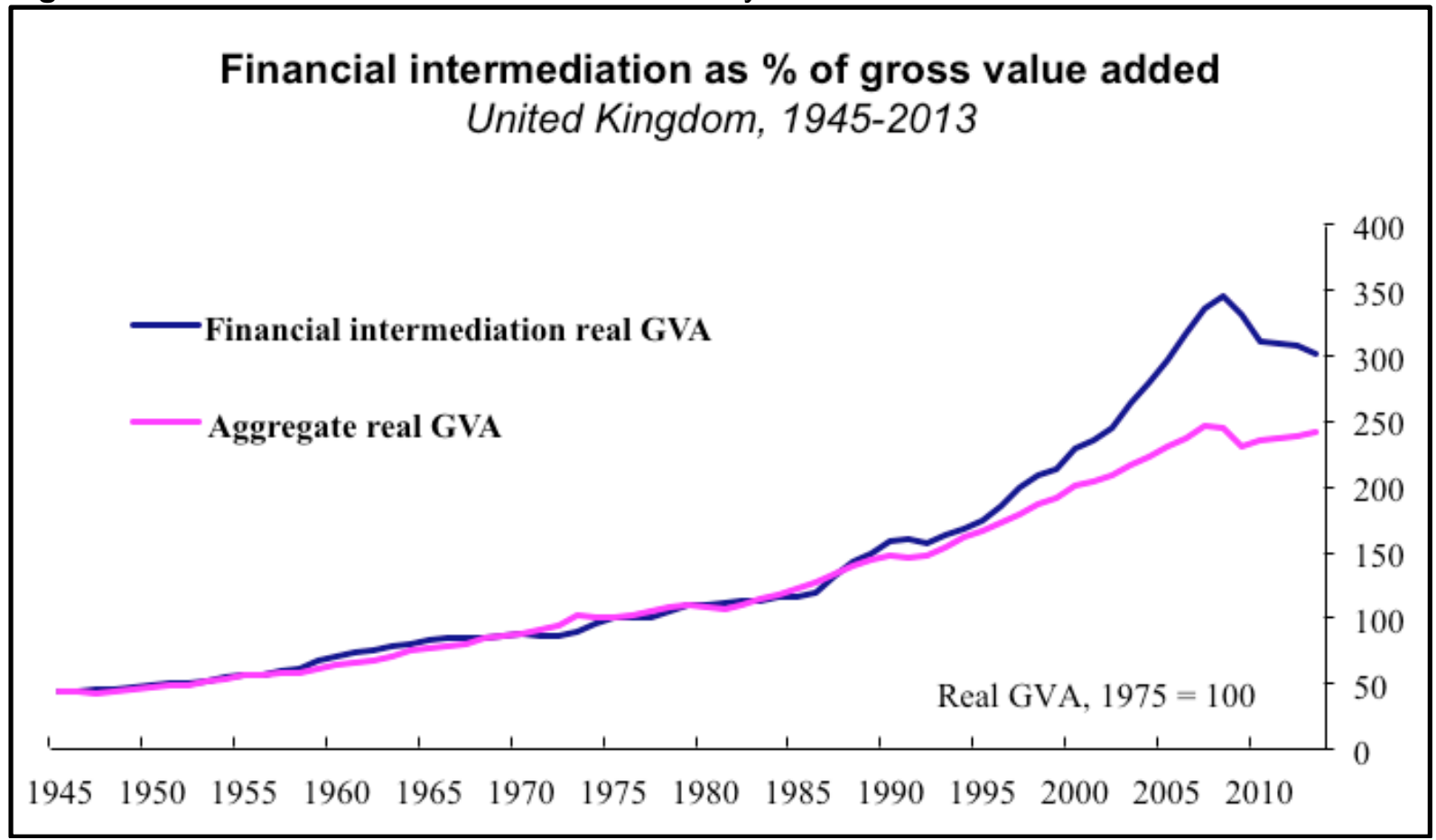

Source: Haldane and Alessandri (2010), updated in Mazzucato and Perez (2014).

Hence, if the goal is smart growth, where will the patient finance come from to fund innovation cycles that can take 15-20 years? As in the case of previous technological revolutions, the answer is: from the state. The state provided most of the high-risk and early funding for the IT revolution and for major advances in healthcare, and we are again witnessing the active role of public finance in funding the next big thing: green technology (Climate Policy Initiative, 2013). Keynes called for a 'socialization of investments' as 'the only means of securing an approximation to full employment' (Keynes, 2006 [1936], p. 246). While a kind of countercyclical socialisation of investments is usually recognised and 
associated with Keynes, he actually called for another type of activity in supplement to private initiative: 'The important thing for government is not to do things which individuals are doing already, and to do them a little better or a little worse; but to do those things which at present are not done at all' (Keynes, 1927, p. 46). Minsky suggested that one form that this Keynesian socialisation of investments should take is of community development banks, which were to fill the gap in banking and financial services for small firms and individuals in certain local communities (Minsky et al., 1993). One could see the work of SIBs as being akin to those of community development banks at the national level.

As discussed in the next section (and supported with empirical data in section 5), SIBs are an increasingly important source of strategic public finance. Such institutions represent a viable alternative to speculative finance, while also fostering the development of private capital markets and financial vehicles for productive projects, thereby helping to reform the financial sector from within. In this way, they promote the creation of a more 'symbiotic' economic ecosystem. SIBs are key sources of patient, long-term committed finance in countries like Brazil, China and Germany, among others.

\section{The roles of SIBs: from countercyclical and capital development to venture capitalist and challenge-led}

Mazzucato and Penna (2014) developed a theoretically-informed typology of SIBs. Starting with a discussion of market failure theory's (MFT) rationales and justifications for these roles, the authors showed the limitations of this explanation by drawing on concepts and insights from heterodox political economy (works in the tradition of Keynes, Schumpeter and Minsky). While that paper was mostly conceptual, the present paper will focus on providing a rich empirical account of the roles of SIBs (see section 6). Here, we provide a brief conceptual description of each role, which is based on the typology fully developed by Mazzucato and Penna (2014).

\section{A. The countercyclical role}

In the past 50 years, financial markets have exacerbated the swings of business cycles, as professional speculators have aimed to obtain short-term gains, even during downturns. The type of financial structures in an economy (for example, the types of banks and markets) is crucial for the workings of the real economy. While some structures are conducive to what Minsky calls 'capital development', which includes privately owned capital equipment, technologies, skills and public infrastructure (Minsky, 1992), others hamper capital development; for example, when speculative finance targets low-risk, short-term gains through speculative and Ponzi schemes. From this perspective, the business cycle problem is not one of risk aversion and failure to coordinate but is about processes of financialisation and speculation. Thus, in playing their countercyclical role, SIBs direct finance to productive opportunities throughout the business cycle. In this sense, this role provides the basis for all others; it underpins investments in the capital development of the economy, the full utilisation of labour resources, the creation of new technologies and sectors, and the direction of techno-economic change through mission-oriented investments.

\section{B. Capital development role}

Schumpeter (1934 [1912]) argued that economic development is a discontinuous endogenous process that results from investments in 'new combinations' (innovations). From the entrepreneur's or the corporation's point of view, the objective of introducing new combinations is to create 'monopoly rents' (also known as 'Schumpeterian rents'). Interventions and investments that seek to address a market failure aim to bring the economy back to the Pareto equilibrium of perfect competition, thereby 'killing' Schumpeterian rents. Therefore, the justification for SIBs' capital development role is not to 
be found in MFT but in the works of developmental economists. Recent work on the developmental state has shown the importance of active public policies (the 'visible hand' of the state) for industrialisation and technological change (Reinert 1999; Amsden, 2001; Chang, 2002). This literature has also emphasised the importance of networks in fostering economic development. In this view, the developmental network state (DNS) can be defined as a decentralised network of different types of state agency that foster innovation and capital development (see Block and Keller, 2011). This network of agencies comprises different actors with various capabilities, which can work together under the coordination of the state. SIBs' capital development role involves supply of capital to, say, public goods areas (infrastructure, new knowledge), but these institutions also often work as the lead public agency (Mathews, 2006) that coordinates the network of actors in the national system of innovation. In order to do this, a SIB may work as an agency to nurture knowledge development, invest in infrastructure, promote strategic trade (such as import substitution, securing sources of materials) and financial leverage, prioritise investments in existing strategic sectors (reinforcing comparative advantages), create 'national champions' that are able to compete in international markets, and provide coherence to economic policies. As we will show in section 5, the developmental role of SIBs underlies (or overlaps with) the venture capitalist and mission-oriented roles, because both often promote a particular type of capital development.

\section{Venture capitalist role}

Mazzucato and Penna (2014) conceptualised the venture capitalist role of SIBs by drawing on Minsky's proposal for community development banks, which he saw as a way to promote the inclusion and development of individuals, firms and communities that were otherwise excluded from the financial system (Minsky et al., 1993). Because the private sector does not provide finance for individual entrepreneurs or high-tech start-ups, SIBs have stepped in and increasingly provided venture capital. Such actions are related to information asymmetries and adverse selection, but also to financial inclusion and financial entrepreneurship, which contributes to capital development, broadly defined as including labour and natural resources. This kind of action helps to reform the financial sector from within, just like Minsky envisaged for community development banks. The challenge in playing the VC role is not so much to provide abundant finance to all small ventures or entrepreneurs but to find and nurture the so-called 'gazelles' (Birch and Medoff, 1994) - that is, young, high-tech firms that often happen to be small or medium enterprises - and to nurture 'animal spirits'. This requires social capital (sometimes networking and comanagement) as much as financial capital. The venture capitalist role can also be seen as a type of microeconomic industrial policy that complements the macroeconomic capital development role by selecting specific firms and projects that have the potential to generate Schumpeterian rents and economic development. Another challenge for SIBs acting as venture capitalists is how to deal with techno-economic risks and uncertainties when they invest in innovation, which is a venture surmounted by fundamental uncertainty (no one knows the chances of success). Because innovation takes a long time to develop, and most attempts end in failure, patient, long-term, committed finance is required. This is the key reason why SIBs have been increasingly mobilised to provide long-term committed venture capital for high-tech start-ups. This venture capitalist role often provides a basis for missionoriented investments, particularly when SIBs seek to promote radical innovations that address societal challenges.

\section{Mission-oriented or challenge-led role}

In market failure theory, societal challenges are seen as negative externalities: they impose a cost to society that is not reflected in prices. However, such a view is limited in its ability to explain what SIBs do to address societal challenges. Science and technology policy research on mission-oriented initiatives provides an alternative and more complete 
conceptualisation of SIBs' systemic role because, in performing this role, the SIBs go beyond addressing a market failure in order to internalise costs. In this role, SIBs help to make things happen that otherwise would not, as Keynes called for the state to do (Keynes, 1926). More importantly, they pave the way for what Polanyi (2001 [1944]) called a 'Great Transformation'. Polanyi showed that capitalist markets are deeply embedded in social and political institutions, rendering the usual static state vs. market juxtaposition meaningless.

Due to their experience and superior position in the economy, SIBs represent a concrete tool through which public policy can promote great transformations (see section 3 ). This occurred in the $19^{\text {th }}$ century, when industrial banks - the predecessors of modern SIBS - played a key role in providing the finance for the construction of the continental European railway network (De Aghion, 1999). This network totally transformed the socio-economic landscape, to the point where Perez (2002) called the third technological revolution 'the age of railroads'.

The new great transformation required to address the large contemporary challenges will not arise from market forces, because markets are 'blind'; that is, incapable of providing a new, qualitatively different direction to economic development. A techno-economic system of innovation may be locked into a self-reinforcing, path-dependent trajectory, because markets are only able to work within the parameters of the prevailing paradigm. Markets are only able to influence the rate of change, not the direction of change. This becomes a problem if the techno-economic trajectory being followed is inferior or suboptimal to what could be achieved with new technologies that are not part of the prevailing system trajectory. In order to coordinate techno-economic development towards a new, qualitatively different route, we need a paradigm shift that will avoid the constant renewal of prevailing trajectories, which occurs if market forces provide directionality to the system. From this perspective, the mission-oriented role of SIBs concerns the creation of a new vision that will coordinate cognitive efforts of different (public and private) agents and direct their action to areas beyond the existing paradigm.

\section{The mission-oriented framework and the importance of SIBs in addressing societal challenges}

The kind of broad-based innovation policy that is often (but not only) driven by 'security' motives has been referred to as mission-oriented because such policies aim to achieve clearly defined technical goals (Ergas, 1987; Freeman, 1996). Rather than just facilitating innovation, with the direction being left to markets, such policies include explicit technological and sectoral directions. Therefore, public financing of innovation is not always a passive reaction to market failures (Arrow, 1962; Peneder, 2008), but an active choice to direct funds towards visionary missions (Mazzucato, 2013a). Understanding the role of the public sector in innovation within a mission-oriented framework is a different analytical exercise to the one derived from the market failure framework (Mazzucato and Penna, 2014). In its most general form, the mission-oriented framework differentiates between public policies that target the development of specific technologies in line with governmental goals ('missions') and those that aim for the institutional development of a system of innovation (Ergas, 1987; Cantner and Pyka, 2001). This framework helps to understand the greater breadth of activities that public spending fosters; not only upstream areas like basic research (as in a market failure framework), but also applied research and early-stage seed financing.

Such mission-oriented investments are featured both in security-led missions (driving technologies behind the military and energy complexes) and in such diverse areas as health and agriculture (Mowery, 2010; Sampat, 2012; Wright, 2012). Also, the public sector's current active role in tackling renewable energy investments can be seen as a new mission related to the green economy. Other new missions include addressing such great societal challenges as the ageing/demographic crisis, inequality, and youth unemployment 
(European Commission, 2011). These challenges - persistent issues that occur at the system level, comprising environmental, demographic, economic and social problems have entered innovation policy agendas as key justifications for action, providing a direction towards which funding policies and innovation efforts should converge.

In countries such as the United States, this kind of mission-oriented funding has come from specialist public agencies within executive departments. Examples include DARPA (in the Department of Defense), the key funder and developer of the Internet and other information and communication technologies; and the National Institutes of Health (NIH) in the Department of Health. In Finland and Israel, mission-oriented funding has taken the form of support for technologies and firms, including public venture capital funds, administered through Sitra in Finland (an early backer of Nokia) and through the Office of the Chief Scientist (OCS) in Israel (which was central in stimulating, seeding and supporting an R\&Dintensive ICT industry) (Breznitz and Ornston, 2013).

In countries like China, Germany and Brazil, active mission-oriented public funding is increasingly coming from public banking institutions (Mazzucato and Penna, 2014); specifically, SIBs. Indeed, a key number of SIBs across the world have been moving beyond their traditional roles of providing counter-cyclical credit and infrastructure funding to also provide funding for innovation through venture capitalist and challenge-led roles. However, the literature on mission-oriented policies has ignored the potential and actual role that SIBs play in promoting and funding new mission-oriented projects. The literature has tended to study demand-side innovation policies, such as the role that R\&D and military procurement has played in the development of radical technologies (Mowery, 2010, 2012; see also Edquist and Zabala-Iturriagagoitia, 2012). The literature has also looked at only a limited number of financial (supply-side) tools; namely, non-reimbursable public finance for basic research and innovation development, such as grants (Sampat, 2012; Wright, 2012), subsidies (including tax credits; see Veugelers, 2012), and innovation prizes (Murray et al., 2012). Consequently, little attention has been paid to alternative forms of finance such as those provided by SIBs.

There are several reasons why it is problematic to ignore the role of SIBs. First, these banks are playing a leading role in funding what could be the most important new international mission: arresting climate change. Climate change (along with energy security) is the reason why the US's stimulus programme (the American Recovery and Reinvestment Act (ARRA) of 2009) was highly green-directed (Grunwald, 2012). Between the announcement of ARRA and February 2012, US\$22.3 billion was devoted to clean energy projects via the Department of Energy (DoE) (DoE, 2012). While this figure may appear impressive, it is only a small fraction of what SIBs are contributing worldwide. In 2012 alone, SIBs invested US $\$ 108.9$ billion in clean energy projects (renewable energy, energy efficiency, and smart grids) (Louw, 2013). In 2012 the largest funders, KfW from Germany and the China Development Bank, spent US\$34.4 billion and US\$26.0 billion, respectively. Meanwhile, the market for green bonds to finance renewable energy projects totalled a mere US $\$ 5.1$ billion (2 per cent of total investments in 2012) (FS-UNEP/BNEF, 2013). Consequently, SIBs were the most important investors in green energy in 2012. To understand other reasons why it is problematic to overlook the mission-oriented role of SIBs, we must understand the differences between the technological missions of the past and the new societal challenges.

In recent years, there has been a call for a return to such policies as a way to address grand societal challenges (Mowery et al., 2010). Missions in the past were often related to welldefined outcomes, such as putting a man on the moon. However, Foray et al. (2012) has claimed that modern missions such as addressing the ageing/demographic problem or climate change are more complex because there is less of a clear technological objective that signals when the mission is accomplished. Contemporary missions aim to address broader and persistent challenges that require long-term commitments to the development 
of many technological solutions and 'a continuing high rate of technical change and a set of institutional changes' (Freeman, 1996, p. 34). The so-called 'Maastricht Memorandum' (Soete and Arundel, 1993) provides a detailed analysis of the differences between 'old' and 'new' mission-oriented projects (Table 1):

'[O]lder projects developed radically new technologies through government procurement projects that were largely isolated from the rest of the economy, though they frequently affected the structure of related industries and could lead to new spin-off technologies that had wide-spread effects on other sectors. In contrast, mission-oriented environmental projects will need to combine procurement with many other policies in order to have pervasive effects on the entire structure of production and consumption within an economy.' (Soete and Arundel, 1993, p. 50)

Although the memorandum specifically focuses on mission-oriented programmes that tackle environmental challenges, its analysis applies to other contemporary challenges (water and food supply, energy efficiency and security, diseases, well-being, demographic change, etc.). All of the challenges present similar characteristics, particularly the fact that new technologies for addressing them will need to substitute for old, incumbent technologies, and will therefore require long-term commitments from both public and private agents.

Table 1: Characteristics of old and new 'mission-oriented' projects

\begin{tabular}{l|l|}
\hline $\begin{array}{l}\text { Old: Defence, nuclear and aerospace } \\
\text { The mission is defined in terms of the number } \\
\text { of technical achievements, with little regard to } \\
\text { their economic feasibility. }\end{array}$ & $\begin{array}{l}\text { The mission is defined in terms of } \\
\text { economically feasible technical solutions to } \\
\text { particular environmental problems. }\end{array}$ \\
\hline $\begin{array}{l}\text { The goals and the direction of technological } \\
\text { development are defined in advance by a small } \\
\text { group of experts. }\end{array}$ & $\begin{array}{l}\text { The direction of technical change is } \\
\text { influenced by a wide range of actors } \\
\text { including government, private firms and } \\
\text { consumer groups. } \\
\text { Decentralised control with a large number } \\
\text { of involved agents. }\end{array}$ \\
\hline $\begin{array}{l}\text { Centralised control within a government } \\
\text { administration. }\end{array}$ & $\begin{array}{l}\text { Diffusion of the results is a central goal and } \\
\text { is actively encouraged. }\end{array}$ \\
$\begin{array}{l}\text { Diffusion of the results outside of the core of } \\
\text { participants is of minor importance or actively } \\
\text { discouraged. }\end{array}$ & $\begin{array}{l}\text { An emphasis on the incrementalist } \\
\text { development of both radical and } \\
\text { incremental innovations in order to permit a } \\
\text { large number of firms to participate. }\end{array}$ \\
\hline $\begin{array}{l}\text { Participation is limited to a small group of firms } \\
\text { due to the emphasis on a small number of } \\
\text { radical technologies. }\end{array}$ & $\begin{array}{l}\text { Complementary policies vital for success } \\
\text { and close attention paid to coherence with } \\
\text { other goals. }\end{array}$ \\
\hline $\begin{array}{l}\text { Self-contained projects with little need for } \\
\text { complementary policies and scant attention } \\
\text { paid to coherence. }\end{array}$ & \multicolumn{2}{|l}{. }
\end{tabular}

Source: Soete and Arundel (1993, p. 51).

This characterisation of old and new missions can be used to highlight the importance of the type of funding sources for the development of challenge-related innovations. Because old missions were defined through a top-down, centralised process, funding sources were executive agencies insulated from the rest of society, which defined the scope of policies and selected a restricted number of firms to develop radical technologies. As these old missions sought to develop radical technologies, regardless of their economic feasibility, grants and subsidies (non-reimbursable funding) or public procurement (which guaranteed demand for technologies) were used successfully. In the case of new missions (environmental and others), it is unlikely that this centralised model will work. There are five reasons for this. Firstly, economic feasibility will be as important as technological feasibility because the new technologies will have to compete with incumbent ones. Secondly, the new missions target technologies for areas in which many stakeholders participate, such as 
energy systems, health systems or the economy at large (as in the case of climate change). Thirdly, in new missions, mass diffusion throughout the economy is crucial and needs to take place together with technology development. Fourthly, incremental innovation is just as important as radical innovation, as in the case of energy efficiency measures that help cut carbon emissions. Finally, mission-oriented policies (such as finance for low-carbon innovation) must be coordinated with other policies that affect the targeted domain (for example, carbon emission standards and targets).

In the present paper, we consider the way in which the increasing role of SIBs in innovation is best understood through the mission-oriented framework discussed above. We also analyse the more traditional roles of SIBs, showing how old and new roles overlap. Our analysis seeks to highlight the role that alternative sources of finance (can) play in missionoriented innovation policies, the impact these sources have on the innovation processes, and the potential for using them in support of new missions.

Given recent critiques of SIBs, any evaluation must be based on what the SIBs are actually trying to achieve. By extending our analysis of their functions to include a Schumpeterian mission-oriented rationale, we also suggest that criteria for evaluation should take these types of objectives into account. We elaborate on this point in the concluding section of this paper. However, not all SIBs are playing mission-oriented roles; in fact, most institutions still promote investments that narrowly aim to close market gaps and correct market failures. Moreover, many SIBs have been ineffective and inefficient in their interventions, which has led to call to reform these institutions by such means as establishing clear mandates and improving governance structures (Gutierrez et al., 2011). We will also return to this important issue in the concluding section.

\section{Methodology}

In section 6, we explore the activities of two state investment banks: the Kreditanstalt für Wiederaufbau (KfW), Germany's SIB; and the Banco Nacional de Desenvolvimento Econômico e Social (BNDES), Brazil's SIB. These two banks were chosen because they are two of the most active public banks investing in innovation and grand challenges; others include the China Development Bank and the European Investment Bank (for a more general discussion of those banks, see Mazzucato and Penna, 2014). Furthermore, because the $\mathrm{KfW}$ is from an industrialised economy and the BNDES is from a developing economy, the two banks provide contrasting examples regarding their institutional environments. Our objective is to illustrate how these two banks have provided much more than just (macro) counter-cyclical lending, or infrastructure investments. They have directed such investments into certain 'smart' areas, such as green and pharmaceuticals, and have developed tools such as public venture capital funds in order to stimulate new firm creation in high-risk areas.

In studying these banks, we adopt an exploratory methodology by use of an open-ended, qualitative case study approach. This method is appropriate for '[investigating] a contemporary phenomenon within its real-life context, especially when the boundaries between phenomenon and context are not clearly evident' and, thus, there are 'many more variables of interest than data points' (Yin, 2003, p. 13). This is the case of the actions undertaken by mission-oriented SIBs: they are a contemporary phenomenon, whereby the actors (SIBs) cannot be dissociated from their contexts (country-specific institutional setting and challenges). The roles performed by SIBs co-evolve with their contexts (for instance, global developments, business cycles, other governmental policies, etc.) and are influenced by a multitude of macro and micro variables. With this method we seek to address an overarching question: How do these banks undertake mission-oriented or challenge-led investments? The case study methodology is appropriate for 'how' questions (Yin, 2003), such as the one we are trying to answer, and is also well suited to explore complex phenomena for theory development (George and Bennett, 2005). Our methodology draws 
on prior theories (revised in previous sections) and studies to guide data collection and analysis. We draw on data from several primary and secondary sources. In what follows, we first compare KfW's and BNDES's institutional and contextual settings (section 5.1), then present and analyse KfW's mission-oriented investments across the four roles described in section 3 (section 5.2), and those of BNDES (section 5.3).

\section{Case study: KfW and BNDES}

\subsection{Institutional context}

It is important to consider each bank's unique institutional context. Both institutions are very active in their respective economies and equally profitable (Table 2), but they differ in certain ways (Table 3). Taking 2012 as benchmark year, we see that KfW's assets and financing portfolio are twice as large as BNDES's, but both display roughly the same level of net profits. On the other hand, the weight of BNDES's investments in its country's economy is much higher than KfW's: BNDES accounts for 21 per cent of total credit in Brazil vs. 13 per cent in the case of KfW in Germany.

Table 2: Performance of KfW and BNDES in 2012

\begin{tabular}{|l|c|c|}
\hline & Germany's KfW & Brazil's BNDES \\
\hline Assets (US\$ Million) & 657,347 & 367,825 \\
\hline $\begin{array}{l}\text { Financing portfolio (US\$ } \\
\text { million) }\end{array}$ & 526,401 & 254,019 \\
\hline Credit/total credit & $12.7 \%$ & $21.0 \%$ \\
\hline Credit/GDP & $15.5 \%$ & $11.3 \%$ \\
\hline Net profit (US\$ million) & 3.063 & 3.009 \\
\hline Non-performing loans & $0.21 \%$ & $0.06 \%$ \\
\hline ROA & $0.47 \%$ & $0.90 \%$ \\
\hline ROE & $11.52 \%$ & $12.50 \%$ \\
\hline Employees & 5190 & 2853 \\
\hline
\end{tabular}

Source: Based on Ferraz et al. (2013).

In terms of institutional characteristics, both SIBs have broad mandates and play the four roles outlined in section three. However, they do not invest in the exact same areas - KfW does not invest in agriculture and BNDES does not provide international aid or credit for education. Furthermore, KfW's regulatory setting is specific, in that it responds directly to the country's minister of finance and minister of economics and technology (since 2013 the minister for economic affairs and energy) and it applies and complies with certain selected rules from the German Banking Act. In contrast, BNDES, like any public and private bank in Brazil, is supervised by the country's securities and exchange commission (CVM) and by the Brazilian federal court of accounts (TCU), which audits BNDES's operations.

Both institutions practise direct lending and (indirect) on-lending through private banks (also known as tier 1 and tier 2 operations). In the case of KfW, direct lending only occurs in case of priority areas (namely those served by the revolving funds from the Marshall Plan) and for international clients. Finally, the way each institution obtains its own funding differs. KfW's original funding came from the Marshall Plan. Unlike other European countries, whose governments simply spent the money, in Germany a bank was created to manage and invest the Marshall funds, which allowed them to be revolved and continuously invested to this day. KfW has grown in size and scope, to the point that most of its funding is now obtained through issuing bonds and selling them in capital markets. Although BNDES's sources of funding have changed considerably over time, since the late 1980s funding has mainly come from the compulsory pension fund for workers (the so-called FAT, which is mandated through the Brazilian constitution) and revolving funds (return on investments). 
Another part of BNDES's funding comes from the Brazilian Treasury. This is particularly the case since the recent global financial crisis, when the Brazilian government transferred funds from the Treasury to BNDES so that it could execute a pronounced counter-cyclical role. We shall return to these characteristics in the concluding section 6 , when we discuss whether the sources of funding matter (and whether other differences in the way a SIB is structured matter).

Table 3: Institutional characteristics of $\mathrm{KfW}$ and BNDES

\begin{tabular}{|c|c|c|}
\hline & KfW & BNDES \\
\hline Year established & 1948 & 1952 \\
\hline $\begin{array}{l}\text { Ownership (state- } \\
\text { owned/private) }\end{array}$ & $100 \%$ state-owned & $100 \%$ state-owned \\
\hline Mandate (broad/narrow) & Broad & Broad \\
\hline Agriculture & & $\mathrm{x}$ \\
\hline Capital markets & $\mathrm{x}$ & $x$ \\
\hline Education credit & $x$ & \\
\hline Exports & $x$ & $x$ \\
\hline Green economy & $\mathrm{x}$ & $\mathrm{x}$ \\
\hline Infrastructure & $\mathrm{x}$ & $\mathrm{x}$ \\
\hline Innovation & $\mathrm{x}$ & $\mathrm{x}$ \\
\hline International aid & $\mathrm{x}$ & \\
\hline Internationalisation & $x$ & $\mathrm{x}$ \\
\hline SMEs & $\mathrm{x}$ & $\mathrm{x}$ \\
\hline Regulatory setting & specific & same as private sector \\
\hline $\begin{array}{l}\text { Financing model } \\
\text { (direct/indirect) }\end{array}$ & $\begin{array}{l}\text { Direct (priority areas } \\
\text { and international } \\
\text { clients) and indirect (all } \\
\text { others) }\end{array}$ & Direct and indirect \\
\hline Funding sources & $\begin{array}{l}\text { Capital markets and } \\
\text { revolving funds }\end{array}$ & $\begin{array}{l}\text { Treasury, workers' } \\
\text { pension funds* and } \\
\text { revolving funds }\end{array}$ \\
\hline $\begin{array}{l}\text { Independent board of } \\
\text { directors? }\end{array}$ & Yes & Yes \\
\hline
\end{tabular}

Source: Based on Ferraz et al. (2013) and annual reports of the institutions.

\subsection{KfW, the German Development Bank}

$\mathrm{KfW}$ was founded in 1948 with the 'mission' of executing and managing the funds for reconstruction of the German economy provided by the Marshall Plan (officially called the European Recovery Program, or ERP). ${ }^{2}$ Therefore, KfW initially played a capital development role, which in the 1960s was supplemented with new programmes aimed at new ventures (SMEs) and innovation. Today KfW plays all four SIB roles, which are increasingly intertwined, particularly when guided by the overarching mission of promoting Germany's energy transition, the so-called Energiewende, a plan to shift the country's energy base from nuclear and fossil fuels to renewables. In this case study, we focus on how the Energiewende plan provides directionality to KfW's activities across the four SIB roles (counter-cyclical, capital development, venture capitalist, and challenge-led). We also focus on how specific programmes are structured and organised, and end with a brief discussion of tangible and intangible outcomes from KfW's activities that aim at environmental and climate protection. While we do not provide a detailed evaluation of these programmes, in the concluding section 7 we will discuss how an evaluative framework could draw on new indicators that are able to capture a SIB's contribution to particular missions.

\footnotetext{
${ }^{2}$ KfW's programmes that still use revolved funds from the Marshall Plan are identified with the acronym ERP.
} 
The organisation of KfW's operations has changed throughout the years and the KfW Group is currently divided into four functional divisions. Two divisions are responsible for promoting investments in the German economy. The Mittelstandsbank (loosely translated as SME Bank) invests in small- and medium-sized enterprises, business start-ups and other commercial clients (such as entrepreneurs) in Germany. The Kommunal- und Privatkundenbank/ Kreditinstitute (Municipal and Private Client Bank/Credit Institute) oversees KfW's housing programmes, energy efficiency and other macro-investments in environmental and climate protection, educational finance for private clients in Germany, as well as financing for public investments in infrastructure projects, urban modernisation, etc. (through, for example, municipalities, regional promotional banks). The other two divisions have an international orientation. The KfW IPEX-Bank is the export-import leg of KfW, promoting internationalisation of German companies and structuring finance for selected projects (including European power plants and grid lines, for instance), while the KfW DEG (Deutsche Investitions- und Entwicklungsgesellschaft) is responsible for development aid and other investments in developing countries. In 2013, KfW established a foundation, the $K f W$ Stiftung, which is responsible for promoting initiatives related to major societal challenges and will result in smart, sustainable and inclusive growth.

The overall result is an organisational structure that covers three roles that SIBs play in capitalist economies: the Mittelstandsbank is responsible for KfW's venture capital and innovation investments; the Kommunal- und Privatkundenbank/Kreditinstitute and the IPEXBank are responsible for KfW's investments in capital development, infrastructure, other public goods, etc.; and the Stiftung is fully concerned with challenge-led initiatives and investments. The fourth role - countercyclical - has been executed by the various $\mathrm{KfW}$ divisions but, since the 2007 global financial crisis, has become an important aspect of the Mittelstandsbank's investments. As we will show below, the Stiftung and all of KfW's other divisions have followed the direction provided by major societal challenges, environment and climate protection in particular. Investing in climate and environmental protection and contributing to Germany's Energiewende is so important to the way KfW operates that even investments in (highly-efficient) coal-fired power plants are justified as a way to help the energy transition to renewable sources, because they allow for relatively large $\mathrm{CO}_{2}$ reductions at relatively low $\mathrm{CO}_{2}$ abatement costs during a period when the priceperformance of renewable energy is not yet attractive (KfW, 2014a).

Therefore, when $\mathrm{KfW}$ announced its countercyclical stimulus package in 2008, it included not only liquidity measures (such as provision of working capital) but also measures directed to areas that would help address societal challenges. This included increased funding for innovation, infrastructure, commercial investments, environmental protection, energy efficiency, and demographic rehabilitation (Table 4). In this sense, KfW's countercyclical investments have overlapped in recent years with capital development, venture capital and challenge-led (green) investments. 
Table 4: Four KfW components of the stimulus packages

\begin{tabular}{|c|c|c|}
\hline $\begin{array}{l}\text { Four KfW } \\
\text { components }\end{array}$ & Description & $\begin{array}{l}\text { Volume of } \\
\text { lending }\end{array}$ \\
\hline $\begin{array}{l}\text { 1. Corporate } \\
\text { financing, particularly } \\
\text { to SMEs }\end{array}$ & - New programme: KfW Special Programme & $€ 40$ billion \\
\hline $\begin{array}{l}\text { 2. Energy-efficient } \\
\text { construction and } \\
\text { rehabilitation }\end{array}$ & $\begin{array}{l}\text { - Stepping up existing programmes for energy- } \\
\text { efficient construction and rehabilitation } \\
\text { - New programme: Senior-friendly conversions }\end{array}$ & $€ 8.5$ billion \\
\hline $\begin{array}{l}\text { 3. Innovation and } \\
\text { energy-efficiency of } \\
\text { enterprises }\end{array}$ & $\begin{array}{l}\text { - Stepping up existing programmes: } \\
\text { - ERP Innovation Programme } \\
\text { - ERP Energy Efficiency Programme } \\
\text { - ERP Start Fund } \\
\text { - New programme: } \\
\text { - KfW Programme Renewable Energies } \\
\text { (Supplement) }\end{array}$ & $€ 1$ billion \\
\hline 4. Infrastructure & $\begin{array}{l}\text { - New programme: Investment Offensive } \\
\text { Infrastructure }\end{array}$ & $€ 3$ billion \\
\hline \multicolumn{2}{|r|}{ - } & $\epsilon \overline{52.5}$ billio \\
\hline
\end{tabular}

Source: KfW (2009, p. 43).

The direction of these investments has been provided by the three pre-established missions, or key challenges, that guide KfW's lending and promotional activities (KfW, 2014b): (1) climate change and environmental protection, (2) globalisation and technical progress, and (3) demographic change. In 2011-2012, more than two-thirds of KfW's financial commitments contributed to at least one of these trends, with climate change and environmental protection representing 40 per cent of all commitments of the KfW Group (Figure 2). Therefore, the challenge of addressing climate change by reducing carbon emissions is the major vector that provides direction to KfW's investments.

Figure 2: Major challenges (or 'themes') that provide direction to KfW's investments

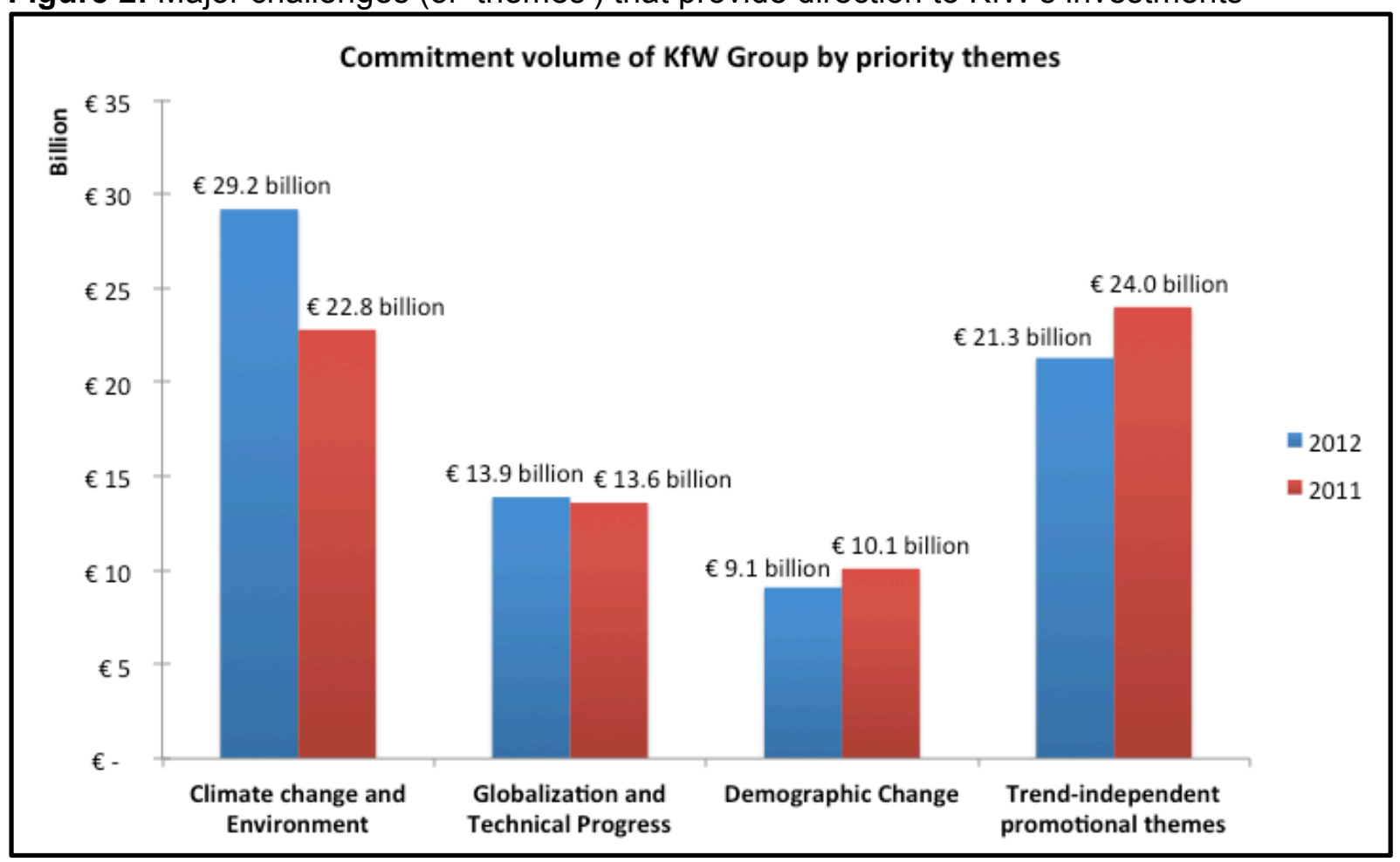

Source: KfW's annual reports. 
KfW's history of investing in energy efficiency and environmental protection dates back to the 1970s, but it was in the 2000s that KfW activities in the area accelerated. In the past decade, Germany has established a climate policy framework (Gumb, 2012) that includes such regulatory initiatives as the Renewable Energy Act (2000), which obliges grid operators to give priority to renewables; the Integrated Energy and Climate Programme (2007); the Climate Initiative (2008); and the Energy Strategy (2010), which established voluntary carbon-emission reduction targets (21 per cent by 2012, 40 per cent by 2020, and 80-95 per cent by 2050, all relative to 1990). The policy framework culminated in 2011 with the bold Energiewende initiative, which set the goal of phasing out nuclear power sources and of having renewable energy sources meet 60 per cent of Germany's gross final energy consumption by 2050. On one hand, this policy framework has meant that Germany has established strict regulations, such as a tight energy savings ordinance or the mandatory use of renewable energy for heating in new buildings. On the other hand, Germany has also assigned KfW with the task of targeting loans to projects that promote energy efficiency and the development of renewable energy sources. As a result, KfW's domestic investments in environmental and climate protection have increased fivefold since 2000 , reaching $€ 22.2$ billion in 2013 (Figure 3).

Figure 3: KfW's domestic investments in environmental and climate protection

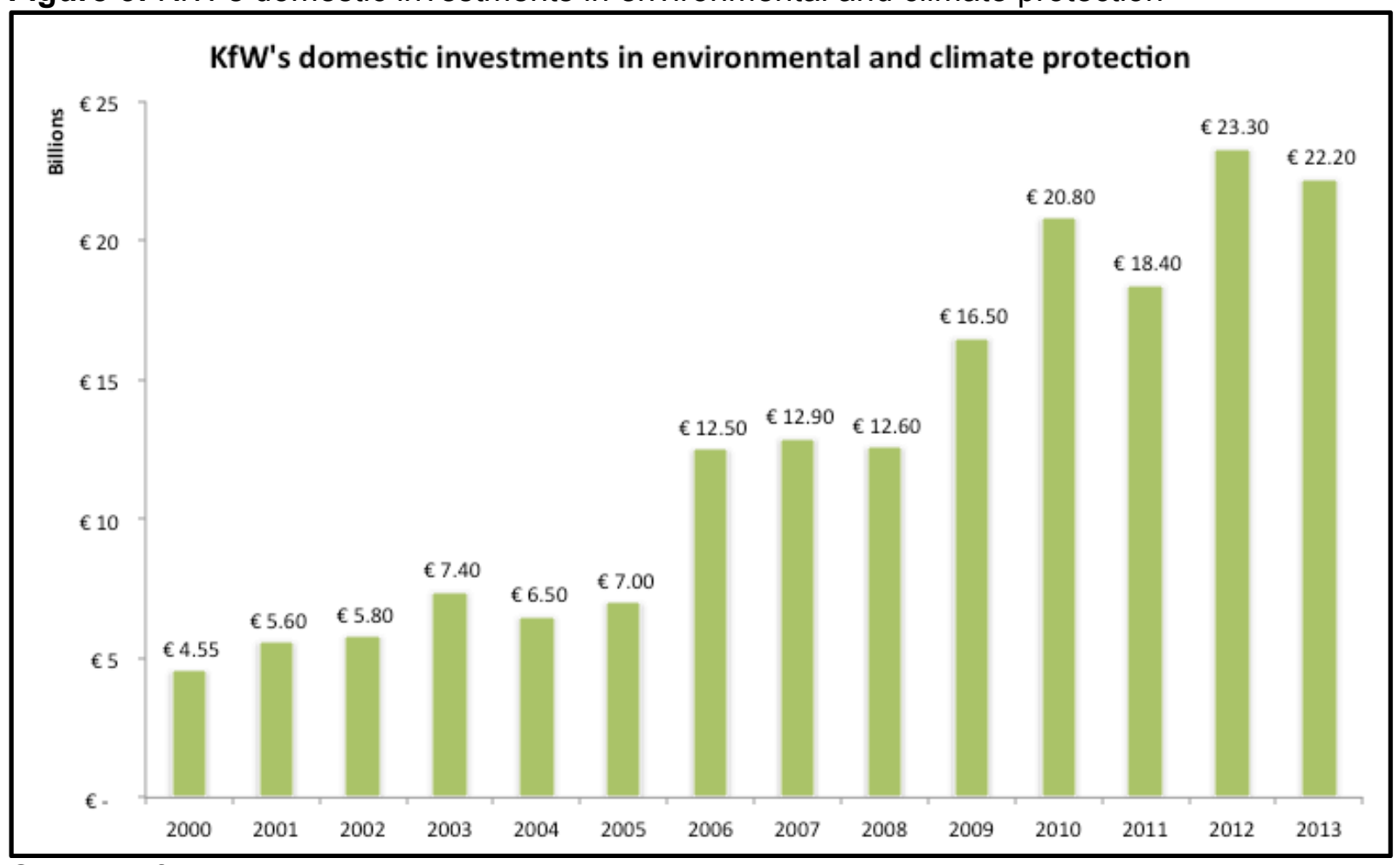

Source: KfW's annual reports.

The structure of KfW's contribution to the Energiewende initiative has been outlined by an action plan that is comprised of new challenge-led programmes and of revised promotional programmes in the areas of capital development (infrastructure), venture capital (SME support), and innovation (Gumb, 2012). In this sense, all of KfW's divisions were included in the Energiewende effort. Renewable energy programmes and innovation investments are executed by the Mittelstandsbank, investments in energy efficiency (in housing and public buildings) and urban infrastructure are carried out by the Kommunalbank, while the IPEXBank promotes project finance for large investments in power plans and energy grids.

In addition to its investment programmes, the Mittelstandsbank also performs a networking, advisory and brokerage role. KfW's mandate establishes that KfW shall provide 'advisory 
services and the implementation of promotional measures in the field of technical progress and innovations' for the promotional areas of (a) SMEs, liberal professionals and start-ups and (b) risk capital. In practice, this means that $\mathrm{KfW}$ performs a coordinating role in the German system of innovation. This is particularly visible in the scope of Germany's 'Energy Turnaround' initiative, in which KfW engages in non-financial activities, such as lobbying, networking, information and consulting (Gumb, 2012). These service-side measures also include training of external consultants in energy efficiency. Such training is a pre-requisite for being listed in KfW's energy efficiency expert database, a network of experienced consultants (engineers and scientists with experience in energy consultancy) that is available for firms that may be willing to invest in energy efficiency but do not know how to proceed. Accordingly, the main goal of providing this expert knowhow is to stimulate firms and other clients to invest in energy efficiency measures. To further incentivise firms to contract expert consultancy services and invest in energy efficiency, KfW also began to provide grants for qualified and independent energy efficiency advice.

Figure $4(a, b)$ displays the disbursements by the Mittelstandsbank since 2000, organised into broad categories. The figure shows that investments by KfW's SME and VC division has substantively increased, reaching $€ 22.6$ billion in 2013, and that investments in environmental and climate protection have taken an increasing share of the Mittelstandsbank's disbursements, particularly after 2011 when it reached almost 50 per cent. Figure 7a also shows that between 2009 and 2011, KfW Mittelstandsbank fulfilled a countercyclical role, which accounted for 30 per cent of its investments in 2009, 22 per cent in 2010, and 3 per cent in 2011, when the Special Programme was phased out. From 2008 to 2013, the bulk of Mittelstandsbank's green investments were accounted for by the renewable energies programme, which totalled $€ 37.6$ billion (or 66 per cent of $€ 56.9$ in green investments), followed by environmental protection and energy efficiency programmes ( $€ 17.9$ billion or 31 per cent). Investments through the offshore wind programme totalled $€ 736$ million (since 2011) and through the Energiewende Financing Initiative, €243 million (in 2012 and 2013).

Figure 4 (a, b): KfW Mittelstandsbank's investments since 2000

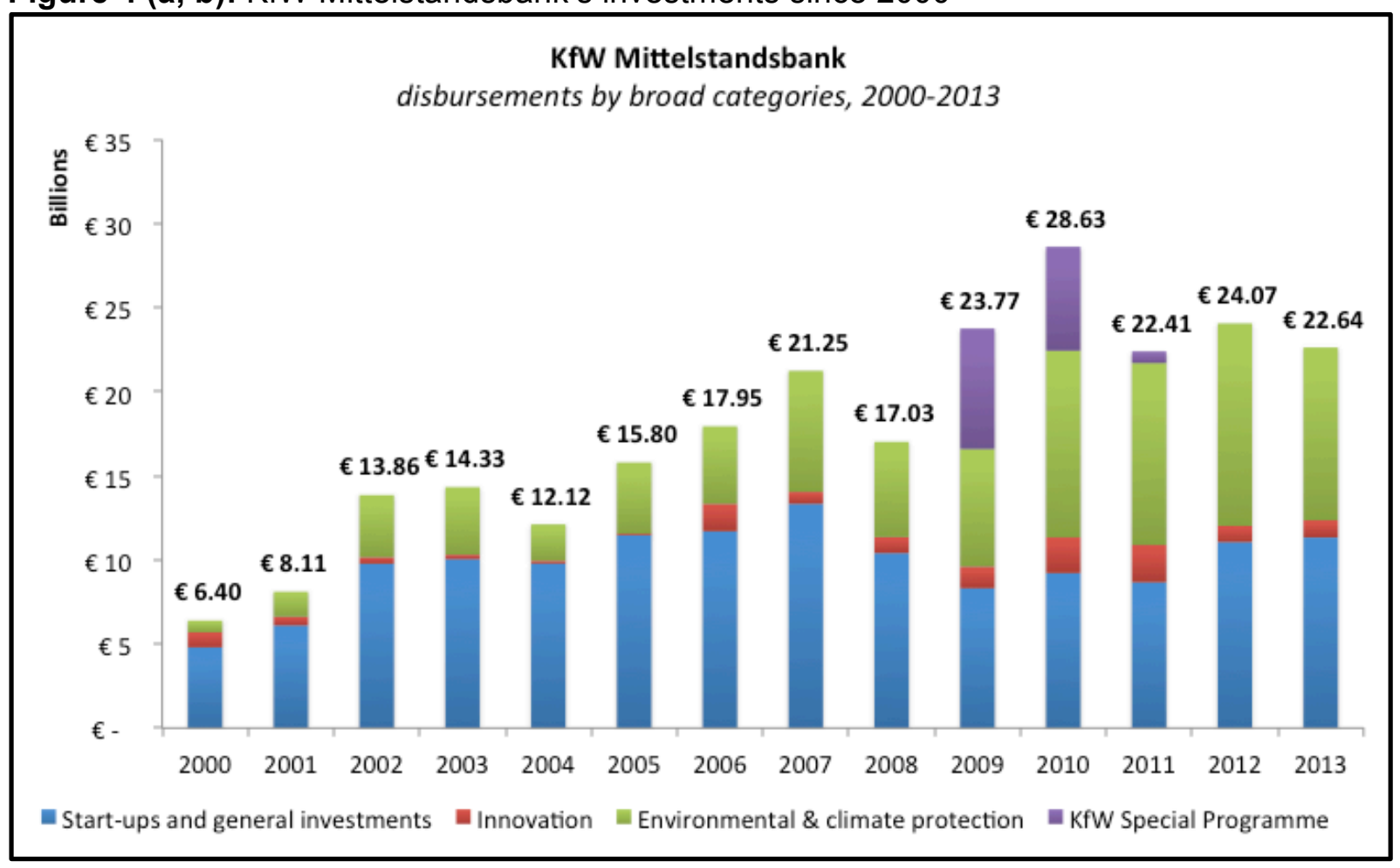




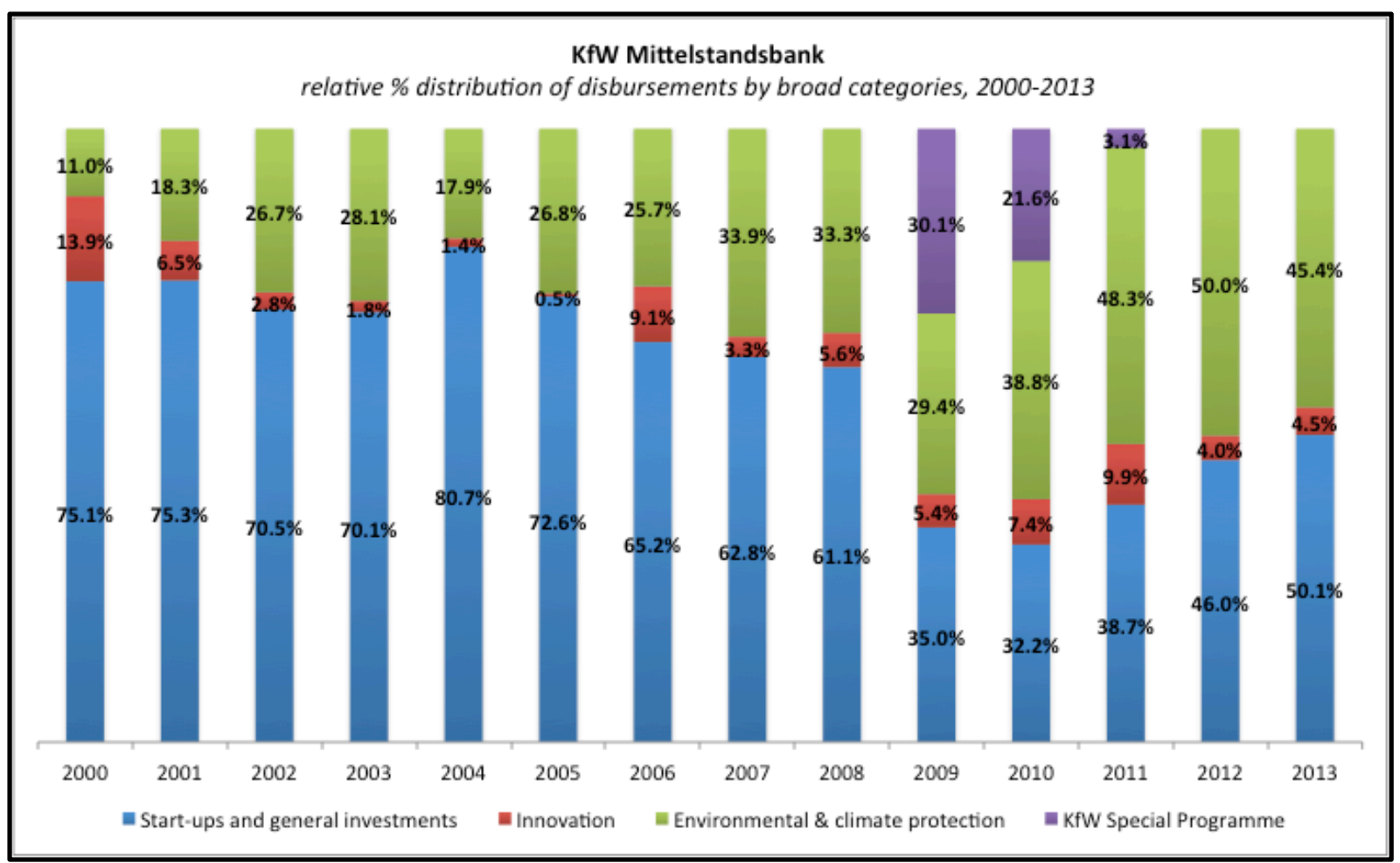

Source: KfW's annual reports.

Figure 5, which displays the investments by KfW's Kommunal- und Privatkundenbank/ Kreditinstitute in 2012 and 2013, shows that the green directionality is also present in KfW's infrastructural investments. The Kommunalsbak's energy efficiency programmes offer interest-subsidised long-term loans (10 years) of up to $€ 50,000$ per housing unit (new buildings) and $€ 75,000$ for existing buildings being rehabilitated; these programmes also include partial debt relief of up to 12.5 per cent. To further incentivise energy efficiency infrastructural investments, $\mathrm{KfW}$ developed its own energy efficiency certificate (KfWEfficienzhaus/KfW-Efficiency House), which became a symbol for the energy efficiency of buildings (Gumb, 2012). 
Figure 5: Investments by KfW's Kommunal- und Privatkundenbank in 2012 and 2013

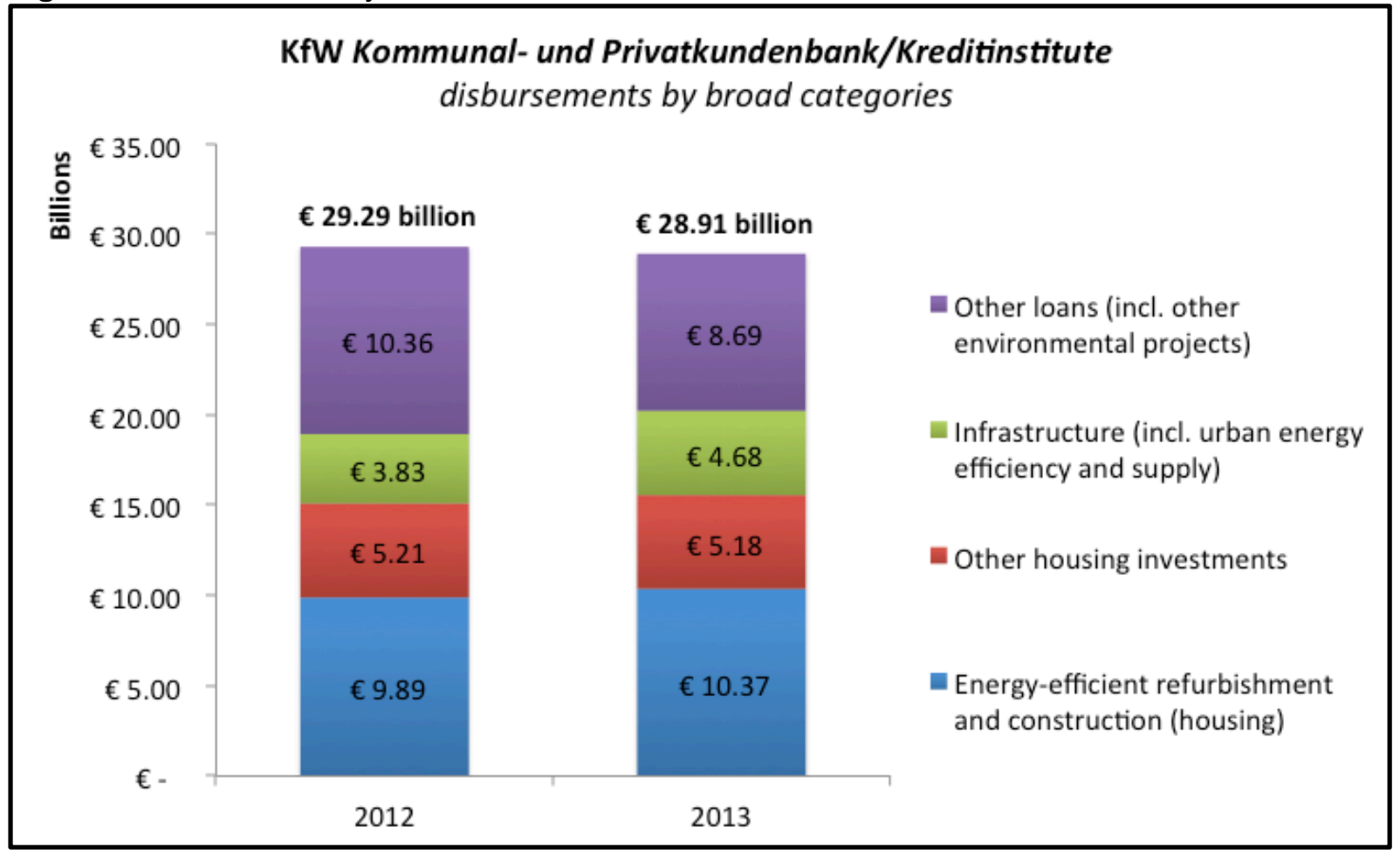

Source: KfW (2014).

Finally, we highlight two examples of project finance structured by KfW IPEX-Bank. The first is the $400 \mathrm{MW}$ offshore wind farm Global Tech I, a flagship offshore energy demonstration project in Germany that was the largest example of offshore wind financing in the world ( $€ 1.05$ billion) and involved high technological risks (due to the distance to the shore and the water depth) (Enting, 2013). KfW alone committed one-third of this funding (another investor in the pool of 17 banks was the EIB). A similar project finance structured by KfW (the first offshore wind farm financed through PE and coordinated by $\mathrm{KfW}$ ) was the $288 \mathrm{MW}$ offshore wind farm Meerwind, in which KfW IPEX-Bank was the largest commercial lender (€195 million) (Enting, 2013).

Therefore, what we see in $\mathrm{KfW}$ is a preference for promotional loans with subsidised credit, which is offered through specific programmes that target particular projects that help address societal challenges. Such programmes are executed by KfW's divisions and subsidiaries. In addition to promotional loans, $\mathrm{KfW}$ also uses equity, particularly for capital intensive and risky projects in such technically uncertain areas as offshore wind. KfW also adopts equity when investing in small technology-based firms and other venture capital investments, but we could not identify whether they target firms that contribute to the societal challenges (for example, new start-ups developing breakthrough energy technologies). As the next subsection shows, such a structure is quite different from that of BNDES, which developed an explicit toolbox for funding mission-oriented innovations.

The results of KfW's recent long-term investments are yet to be seen (and will need to be independently evaluated). However, it is possible to highlight some existing outcomes reported by KfW. Regarding its recent countercyclical investments, KfW estimates that over its three years of existence the Special Programme accounted for the creation or maintenance of 750,000 job posts. Other $\mathrm{KfW}$ anti-cyclical investments under Germany's stimulus packages secured a further 450,000 jobs. An external evaluation (reported in Duve, 2007 ) has estimated that KfW's building rehabilitation investments in 2006 (through the Kommunalbank) created 65,000 jobs and allowed for greenhouse gas emissions to be 
reduced by 700,000 tons of $\mathrm{CO}_{2}$ equivalents per year, while energy demand was reduced by 40 per cent. $\mathrm{KfW}$ also reports that its energy-efficient construction and refurbishment programmes led to emission cuts of more than one million tons of $\mathrm{CO}_{2}$ equivalents per year in 2009 and 2011, and about 600,000 tons in 2011, while securing on average 268,000 job positions per year (KfW, 2013, p. 6). The same KfW report estimates that $\mathrm{KfW}$ renewable energies programmes (in Germany, excluding KfW IPEX-Bank's project finance) created an average of 50,000 jobs per year in 2009-2011 and helped cut greenhouse gas emissions by 3.7 million tons in 2009, 4.8 million tons in 2010, and 5.1 million tons in 2011, thereby avoiding more than $€ 1$ billion in costs associated with fossil fuel imports (KfW, 2012, p. 6). Furthermore, KfW's renewable energies programmes in Germany helped to mobilise private investments, with private investors committing one extra euro for every three euros invested by KfW.

\subsection{BNDES, the Brazilian Development Bank}

BNDES was founded in 1952 to finance the construction of key infrastructural projects, the building of basic industries, and the mechanisation of agriculture; in other words, to fund Brazil's catch-up strategies. In the 1960s and 1970s, BNDES focused on promoting import substitution industrial policies, thereby furthering the capital development role. In the 1980s, it began to develop financial instruments for new ventures and SMEs and in the 1990s it experimented with specific programmes to finance innovation and high-tech firms. In the last decade, BNDES has enlarged its operational scope with mission-oriented innovation investments. Targeted sectoral programmes such as Prosoft (which targets innovation in the software industry) and Profarma (which targets pharmaceutical innovation) were established. Our analysis of BNDES's challenge-oriented investments focuses on how they contribute to Brazil's mission of promoting 'smart' (innovation-led) growth. ${ }^{3}$ As with the KfW study, we will attempt to pay particular attention to aspects of directionality and structural organisation of BNDES's investments. ${ }^{4}$

As the Brazilian Federal government shifts its impetus towards industrial policy, one of its defined missions has been to address the challenge of increasing expenditures in R\&D and innovation. The mission has targeted specific, capital-intensive manufacturing sectors and, in doing so, has enlisted BNDES as the largest funding agency, which cooperates with other public agencies such as FINEP (Brazil's innovation finance agency). Like KfW, BNDES has defined three themes to guide its investments. These are three interrelated issues that represent 'the new challenges to be tackled: innovation [smart growth], socio-environmental development [environmentally sustainable growth], as well as local and regional development, prioritising the less developed regions [inclusive growth] in Brazil'. ${ }^{5}$

BNDES's organisational structure is more complex than that of $\mathrm{KfW}$, with eight managing areas that are responsible for a total of 22 operational divisions (there is also a $23^{\text {rd }}$ division, which is responsible for the internal auditing). The so-called BNDES System also includes three subsidiaries that complement BNDES's main structure. The first is FINAME (the Special Agency for Industrial Financing), which is BNDES's export-import arm and was previously a fund for managing earmarked public resources for financing purchase, sales

\footnotetext{
${ }^{3}$ Entering a new phase of economic development will require Brazil to become a 'maker' of technologies and innovations (Schapiro, 2012). This involves augmenting national investments in R\&D and also establishing an 'innovation culture' amongst Brazilian firms (Cavalcante and de Negri, 2011; Negri et al., 2005).

${ }^{4}$ The authors are grateful to Valéria Bastos, an economist at BNDES, who shared not only the data on BNDES disbursements for innovation in the 2000-2010 period (Bastos, 2012), but also her knowledge about BNDES's innovation financing activities. We are also grateful to João Pieroni, manager at BNDES's pharmaceutical department, for articles, data and information provided during several email exchanges between March and May, 2013. An unstructured interview with Mr Pieroni was also carried out on March $11^{\text {th }}, 2013$.

${ }^{5}$ Source: http://www.bndes.gov.br/SiteBNDES/bndes/bndes en/Institucional/The BNDES/mission.html; accessed on 4/9/2013.
} 
operations and exports of Brazilian machinery and equipment, as well as imports of goods of the same nature. The second is BNDESPar, which is responsible for capitalisation operations and equity investments in the Brazilian capital market. The third subsidiary is BNDES PIc., headquartered in London, which promotes the internationalisation of Brazilian companies and seeks to attract international investors to fund BNDES-led investment projects in Brazil. The matching between BNDES's managing areas and operational divisions with the four SIB roles is less straightforward than KfW's organisational structure. Some managing areas (for example, those that include human resources or the legal division) are concerned with and provide support to all roles. Others, such as those devoted to agriculture or infrastructure, are more specialised and could be seen as performing the capital development role. Yet others are engaged in more than one role, such as the managing area devoted to venture capital, capital markets, and industrialisation.

The overlapping of areas/divisions and roles in BNDES is less obvious than in KfW. Therefore, it is not easy to identify how societal challenges give direction to investments carried out by each managing area and division. Instead, it is possible to look at how BNDES developed specific, targeted programmes that contribute to the fulfilment of the smart growth mission. These programmes are closely related to the industrial policy plans established by the Brazilian Federal government since 2003, when it established the Trade, Technology and Industrial Policy plan (PITCE). In the period prior to 2011, the Brazilian government established two other plans, each of which gave increasing emphasis to innovation and strategic sectors. The latest plan, Plano Brasil Maior ('Greater Brazil Plan' PBM), which is due to last until 2014, prioritised the following six strategic sectors: IT, the pharmaceutics and health industry, oil and gas, the defence industrial complex, aerospace, and renewables.

Support for innovation became a strategic priority at BNDES following the 2003 industrial policy plan (PITCE). Innovation was converted into the key variable in BNDES's Operational Policy document, which stated that innovation support 'will [henceforth] also be considered of maximum priority by BNDES' (cited in Schapiro, 2012, p. 24). New tools and programmes were then designed to support innovation. Although the inclusion of innovation as a core principle only came in the 2000s, BNDES began its financial support for innovation in the 1990s. Figure 6 presents a timeline of initiatives and experiments with financing innovation that the Brazilian development bank has undertaken. The trajectory is closely linked to the recent sectoral approach of industrial policy plans in Brazil. 
Figure 6: Timeline of the introduction of different tools for funding for innovation

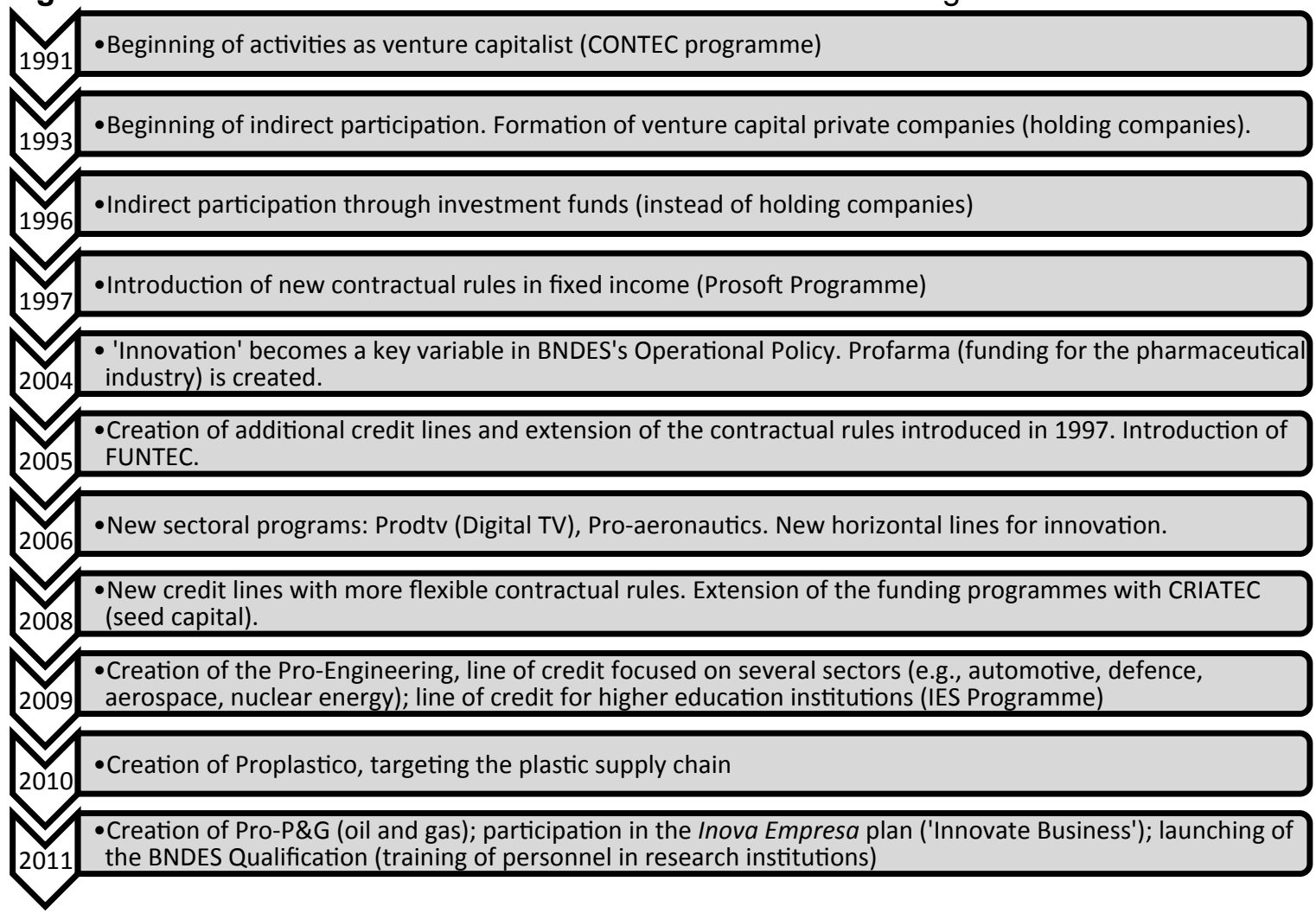

Source: Based on Chart 3 in Schapiro (2012), with additions based on Bastos (2012).

In the 1990s, BNDES adopted a proactive approach to funding innovation when it established its first targeted funding for innovation, which focused on companies in the software sector (Bastos, 2012). The so-called Prosoft was the Bank's first vertical line of credit (a targeted fixed income tool) that provided flexible and generous conditions for innovators. The Prosoft experience was copied in the form of a new programme for the pharmaceutical sector, Profarma. In this way, BNDES started to fund smart growth embedded in its promotion of industrialisation, and this smart-growth began to give a direction to BNDES's capital development and VC initiatives. Subsequently, BNDES established FUNTEC, a non-refundable category of finance for technology and innovation, funded with part of the bank's own profits (Bastos, 2012), which targets strategic sectors. ${ }^{6}$ It also created new sectoral programmes and extended its funding programme to pre-start-up companies (Schapiro, 2012) with the creation of the CRIATEC investment fund (which receives 80 per cent of its resources from BNDES). CRIATEC provides seed capital to startups, mainly from the ICT and biotechnology sectors (Cherobim et al., 2011). The result of this two-decade-long process was the establishment of legal, managerial and institutional capacity inside BNDES, with a set of different types of funding for innovation under four categories (variable and fixed income; variable income; fixed income; and non-refundable resources), which covered an array of tools and programmes (Figure 7).

\footnotetext{
${ }^{6}$ The list of sectors is constantly being reviewed, but currently includes energy, environment, pharma, electronics, new materials, chemicals, transport and oil and gas (Bastos, 2012).
} 
Figure 7: The toolbox of funding for innovation from BNDES

\begin{tabular}{|c|c|c|}
\hline & $\begin{array}{c}\text { Funding } \\
\text { programmes/tools }\end{array}$ & Focus \\
\hline \multirow{4}{*}{$\begin{array}{l}\text { Variable income } \\
\text { (equity) E fixed } \\
\text { income }\end{array}$} & Innovative capital & Business strategy/model \\
\hline & Technological innovation & \multirow{2}{*}{ Innovation project } \\
\hline & Productive innovation & \\
\hline & $\begin{array}{l}\text { Prosoft, Profarma, Protvd, Pro- } \\
\text { aeronautics and Pro- } \\
\text { engineering }\end{array}$ & Strategic sectors \\
\hline \multirow{3}{*}{$\begin{array}{l}\text { Variable } \\
\text { (equity) }\end{array}$} & Investment (VC) funds & \multirow{3}{*}{$\begin{array}{l}\text { Establishment of highly } \\
\text { innovative enterprises }\end{array}$} \\
\hline & $\begin{array}{l}\text { Indirect participation in } \\
\text { investment funds }\end{array}$ & \\
\hline & Criatec (seed money) & \\
\hline Fixed income & BNDES card & Innovative projects by SMEs \\
\hline $\begin{array}{l}\text { Non-refundable } \\
\text { resources }\end{array}$ & Funtec (technology fund) & $\begin{array}{c}\text { Funding for research institutes } \\
\text { (basic R\&D) in targeted areas } \\
\text { of future potential and national } \\
\text { interest }\end{array}$ \\
\hline
\end{tabular}

Source: Based on Fig. 1 in Coutinho et al. (2011), with additions based on Bastos (2012) and Schapiro (2012).

Apart from the sectoral focus that some programmes have (each involving different levels of uncertainty and of capital intensity), BNDES's tools and programmes focus on different areas of the risk landscape. As shown in Figure 8, BNDES toolbox of innovation funding covers all stages in the life-cycle of an innovative enterprise.

Figure 8: BNDES's types of funding for innovation for the different stages of the innovative enterprise

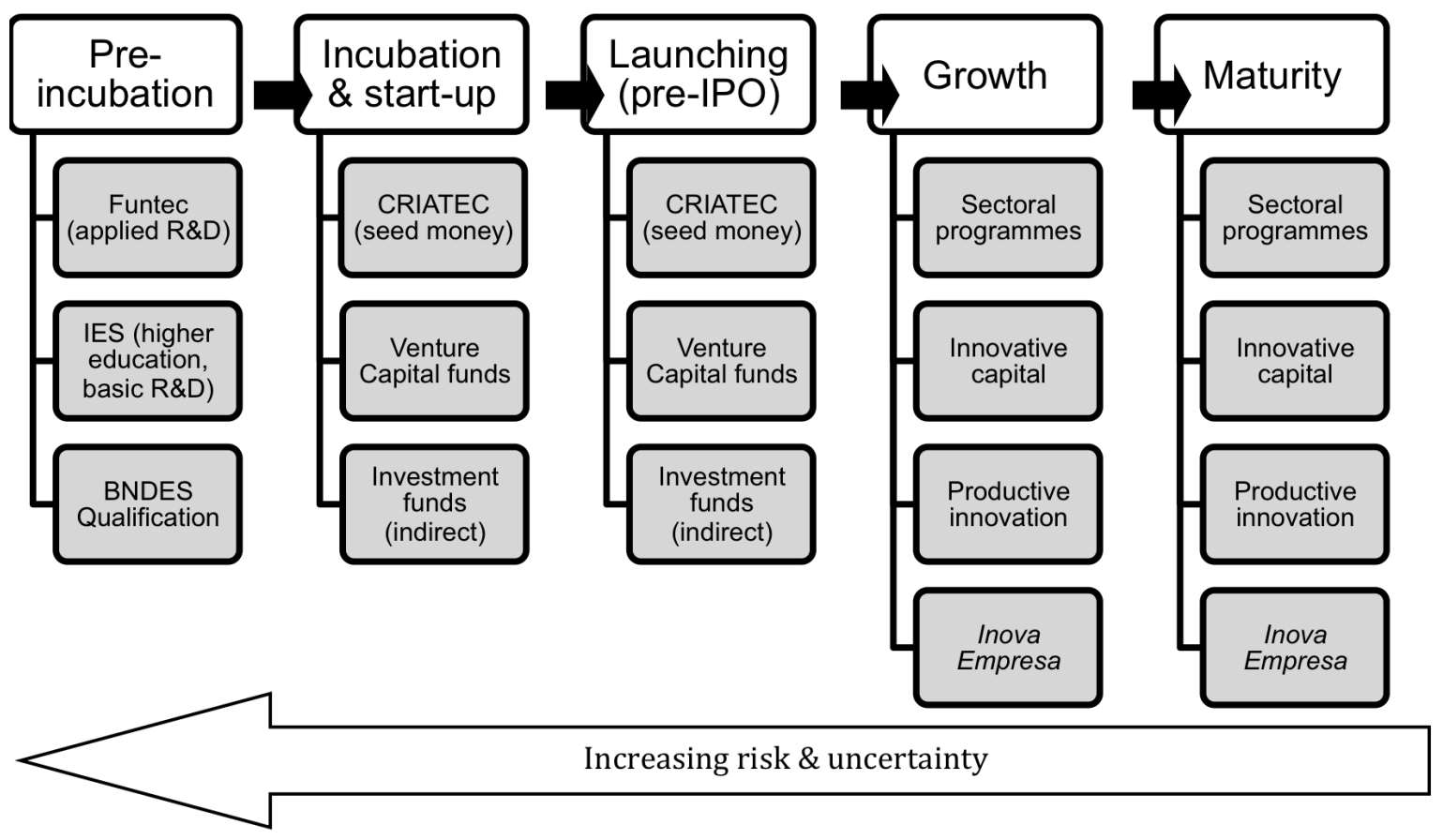

Source: Authors' construction

The toolbox for the support of innovation presents certain characteristics that meet the specificities of an innovation project or innovative firm: 
- Collateral and repayment obligations decrease with the increased risk/uncertainty of the project or targeted area. The extreme case seems to be FUNTEC, whereby BNDES fulfils the role of an angel investor, without any financial obligation to the receivers. ${ }^{7}$ However, the receivers are required to fulfil their technological mission and to clearly establish an intellectual property sharing agreement. FUNTEC targets those areas with future potential, which can result in commercial technologies that represent a radical departure from incumbent sectors. These areas are energy, environment (green-tech), electronics, new materials, chemistry, and electric vehicles. In the case of small innovative firms in their incubation, start-up or launching stages, BNDES adopts innovation funding based on equity investments, and funding requests are evaluated in the light of potential future results. This requires BNDES to employ not only finance specialists but also experts in each sector in which it invests. For innovative projects (as opposed to innovative firms), BNDES uses risk contracts in which it agrees to fund 90 per cent of the project and shares in future sales of the innovative product, if successful (BNDES, 2012). ${ }^{8}$

- The younger the innovating firm, the more involvement BNDES has in its management. ${ }^{9}$ During the incubation, start-up and launching stages, BNDES acts as a venture capitalist, supplying not only seed capital but actively engaging in the management and governance of the firm. Although BNDES does not hold majority stakes in these young companies, the standard stockholder agreement of this mode of funding grants BNDES participation in the firm's board of directors and direct access to corporate information (Cherobim et al., 2011; Schapiro, 2012). In this way, BNDES not only acts as a financier but is also directly involved in the implementation and revisions of the firms' business plan until its IPO, which, according to Shapiro (2012) is BNDES's preferred withdrawal option: 'Firstly because it guarantees the return of its investment in market conditions, and secondly, because indirectly, it favours the development of the Brazilian capital market, which in turn expands its investment capacity in new innovative companies due to the broader horizon of disinvestment in the future' (p. 32). These firms are usually required to offer their shares in the Brazilian New Market, a new listing segment with higher protection for minority shareholders (BNDES, 2012).

- Innovative projects of non-public or established companies are supported with fixedincome financial contracts with flexible conditions. BNDES approached the issue of financing innovation by making three main assumptions: (a) that innovative projects are inherently uncertain; (b) that some established firms seeking funds for innovation have no track record (particularly in light of the absence of an innovation culture in the Brazilian business sector); and (c) that these companies do not always have collateral to offer (Schapiro, 2012). Therefore, evaluation of these projects is based on their future prospects (BNDES, 2012) and not on the company's credit score, which requires expert know-how on the part of BNDES. In this way, BNDES is actively creating new market and technological opportunities, expanding the innovation landscape for the private sector to exploit. Due to the level of uncertainty involved, the allocation of resources is gradual and involves close and ongoing monitoring of the innovative project (Schapiro, 2012, p. 28). This informal structure means that the non-fulfilment of contractual obligations does not necessarily constitute contractual default.

Figure 9 shows BNDES's innovation disbursements by programme. The figure reveals that, in 2010, the largest amount of funds went to the Prosoft programme (38 per cent), followed by variable-income (VC) funds (20 per cent) and the Innovative Capital horizontal line of

\footnotetext{
${ }^{7}$ Note that receivers are scientific and technology institutions in partnership with business enterprises.

${ }^{8}$ However, the use of this type of contract is still incipient at BNDES (interview by email with Felipe Marques, from BNDES economic research department, on 30/8/2013).

${ }^{9}$ In cases where BNDES buys quotas in private VC funds, co-management is fulfilled by the fund.
} 
credit (17 per cent). The aggregate figure of innovation investments in the 2000 s reveals that the majority of funds (51.2 per cent) went to strategic sectors (Prosoft, Profarma and FUNTEC), with BNDESPAR and variable-income funds investing a further 31 per cent of the total, with the remainder (17.8 per cent) being applied through fixed-income contracts. These statistics indicate how BNDES is actively picking strategic sectors with its innovation programmes. This is also visible in Figure 10, which shows BNDES's investments in the green economy and for environmental and climate protection since 2000.

Figure 9: BNDES's total disbursements for innovation programme and tools

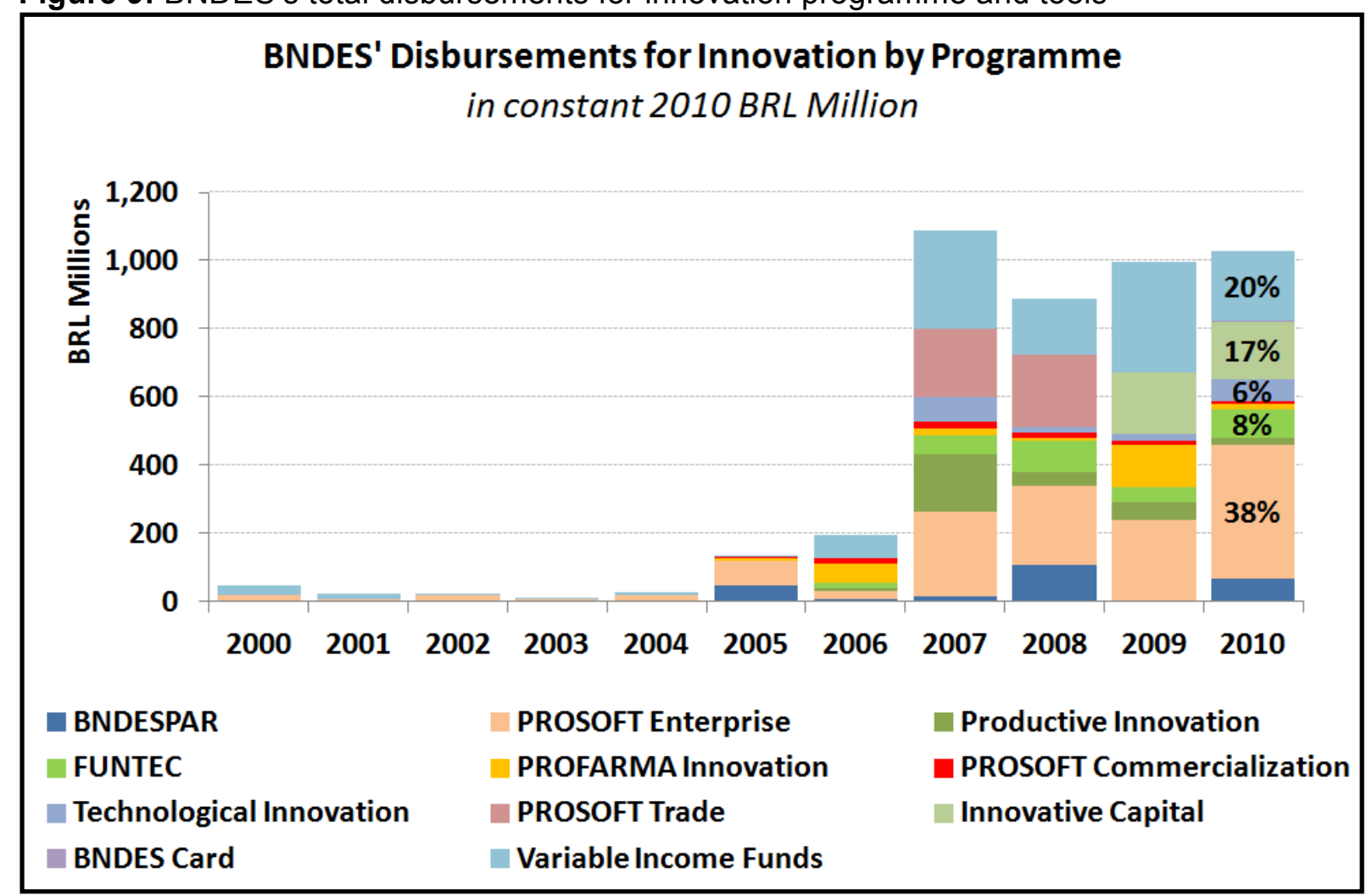

Source: Bastos (2012). 
Figure 10: BNDES's green investments

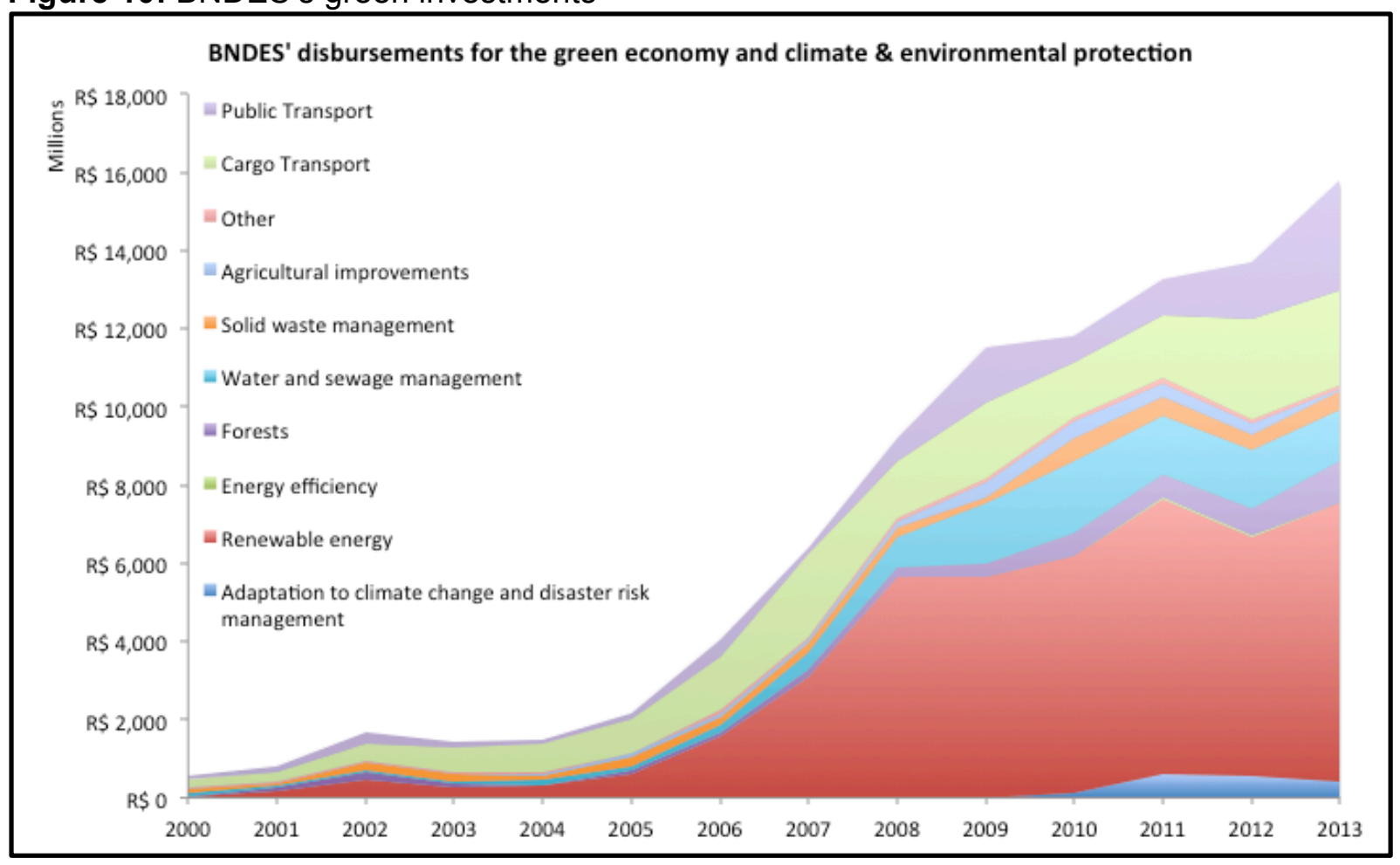

Source: Data obtained from BNDES (emails dated 8 and 9 October 2014).

The bulk of BNDES's 'green' investments go towards renewable energy projects (the figure excludes investments in large hydroelectricity power plants). Because sustainability is very important for BNDES, it has a managing area (division) that is responsible for such investments. At BNDES, the green economy is broadly defined to include projects in renewable energy (biofuel, solar and wind energy), energy efficiency (in firms), sustainable transport (cargo and public, such as diffusion of electric and hybrid vehicles), and water, forest and waste management (including grants to local communities that protect their natural resources).

To further discuss the outcomes of BNDES' mission-oriented innovation investments, we will focus on three specific programmes or types of investments: BNDESPar's equity investments in high-tech firms (gazelles); CRIATEC's seed investments; and Profarma Innovation, BNDES' programme that targets pharmaceutical innovation.

- According to data published in Mattos (2008), BNDESPAR held direct investments in about three dozen small and mid-sized innovative companies; one-third of the amount was invested in ICT and electronics companies and 15 per cent in biotech or biopharma companies. The data also shows that BNDES has invested in nanotech, defence, and medical equipment companies, among others. These companies offer prospects of very high returns due to the inherent risks involved. Examples of successful seed capital investments by BNDES (that is, investments from which BNDESPAR managed to exit through an IPO ${ }^{10}$ ) include the software companies Totvs (IPO in 2006) and Bematech (IPO in 2007), the oil industry high-tech supplier Lupatech (IPO in 2006), and the fertiliser producer Nutriplant (IPO in 2008). 'The return of BNDESPAR investments in venture and seed capital was about $536 \%$ from 2005 to 2007 , or $85 \%$ per year, which reveals solid investment strategies and a laudable selection of investment managers' (Mattos, 2008, p. 23). Thus, BNDES's equity investment strategy in support of innovative

\footnotetext{
${ }^{10}$ Success may be defined in other terms, and IPOs are not always the best criterion (cf. Lazonick and Tulum, 2011). However, we have drawn on this definition of success as it is also one adopted by BNDES.
} 
enterprises has established a strong link between risk-sharing and reward-sharing, helping to promote a type of risk-reward nexus that is conducive to the capital development of the Brazilian economy. In this way, these investments contribute to BNDES's profits, which translate into dividends to the Brazilian Treasury and returns to Brazilian workers' social security funds (FAT).

- Since 2008, an important portion of BNDES' equity investments have taken place through the CRIATEC investment fund, which supplies seed capital for innovative startup companies that develop disruptive technologies in high-tech and new sectors. In contrast to 'old' mission-oriented public R\&D grants that are non-reimbursable ('not-forprofit'), CRIATEC 'aims to achieve capital gains through long-term investment in earlystage companies (including 'zero stage') that have an innovative profile and [offer] highreturn prospects. ${ }^{11}$ In its four years of existence, the value of the CRIATEC portfolio has grown at a rate of 50 per cent per annum, ${ }^{12}$ with a compound annual growth rate (CARG) per vintage of investments varying between 45 per cent and 160 per cent (Ramundo, 2013). However, these results are yet to materialise, as BNDES has not yet 'exited' from the investments in these companies (none has yet carried an IPO); the deadline for this to occur is 2017. While some investments may fail, others offer prospects of huge returns to BNDES and the other private investors. An exemplary company - which presents high potential for large returns - is Bug Agentes Biológicos S.A., which develops insects that substitute for pesticides in the control of agricultural plagues and has been voted the most innovative company in Brazil and $33^{\text {rd }}$ in the world (Zanatta, 2012).

- Profarma has gone through two complete rounds or 'stages' (2004-2007 and 20072012). The second phase of the Profarma gave stronger emphasis to the Innovation subprogramme, with the portfolio of innovation investments increasing from BRL 102 million (c. US $\$ 57$ million) in the first stage to BRL 424 million (c. US $\$ 227$ million) in the second stage (as of December 2011). Consequently, the share of the Innovation sub-programme in the entire Profarma portfolio increased from 12 per cent in the first stage to 56 per cent in the second (Palmeira Filho et al., 2012). A third stage has been announced in April 2013 (to last until 2017), which will expand Profarma's scope to include a new subprogramme, the 'Profarma Biotechnology' (the guidelines of which are still being structured). ${ }^{13}$ This signifies a new emphasis on the development of radical, disruptive (biotech) innovations, which are naturally riskier and more uncertain than incremental innovations (such as production of generic drugs or new formulations of an existing drug). Indicators ${ }^{14}$ show that the first stage of the Profarma (2003-2007) resulted in increased innovation activities by the Brazilian pharmaceutical sector. Data from several PINTECs (the Brazilian business R\&D and innovation surveys) show that pharmaceutical companies' total R\&D investments relative to revenues increased from 3.4 per cent in 2003 to 4.2 per cent in 2005 and to 4.9 per cent in 2008. In-house R\&D investments to revenues almost tripled, from 0.5 per cent to 0.7 per cent to 1.4 per cent, respectively, while the number of employees in R\&D activities almost doubled (from 913 in 2003 to 1761 in 2008). Considering the size of the Profarma Innovation portfolio and total R\&D investments by pharmaceutical firms, BNDES was responsible for funding 48.6 per cent of total R\&D activities and 12.1 per cent of in-house activities. One criticism of Profarma's investments in innovation is that most of the projects it funded consisted of 'me-too' drugs (new formulations or presentations of existing drugs) and of generic drugs, with 5.7 per cent of the projects representing global innovations (Palmeira Filho et al., 2012). However, all types of projects potentially help foster an innovation culture and

\footnotetext{
${ }^{11}$ See http://www.fundocriatec.com.br/, accessed on 12/6/2013.

12 See http://www.fundocriatec.com.br/capital.php?escolha=54, accessed on 12/6/2013.

${ }^{13}$ In April 2013, BNDES also announced the creation of a new programme of funding of medical equipment, a joint programme with FINEP aimed at funding the development of medical equipment and of diagnostics processes to be used in the Brazilian national health system (so-called SUS). Thus, BNDES is moving beyond funding drug developments and towards a broad range of innovation in the health industrial complex.

${ }^{14}$ Data in this paragraph is based on Palmeira Filho et al. (2012).
} 
improve access of the Brazilian population to medicaments. As we argued in the introduction, new missions require investments in both radical and incremental innovations.

\section{Discussion and conclusion}

Our case study and analysis showed how KfW and BNDES play the Schumpeterian 'mission-oriented' role. As argued in Mazzucato and Penna (2014), these kind of missionoriented investments cannot be explained by the market failure approach because such investments are creating markets (and technologies, firms and sectors), not just fixing them. However, the mission-oriented literature has not yet looked at these public banks. The present paper can be viewed as a call for the Schumpeterian tradition to be applied to public finance. Governments establish mission-oriented programmes in targeted areas not because there is a market in those areas that is not working correctly, but because the areas do not exist at all (and, therefore, 'markets' do not exist there). Mission-oriented projects are about creating new technological landscapes and innovative solutions to fulfil the governmental mission.

The fact that it is SIBs that are currently making key investments in new technologies and sectors suggests that SIBs are playing a 'dynamising' role. Analyses of the performance of such banks must take into consideration the different level of risk - beyond economic and financial risk measures - that is being absorbed. Furthermore, for such risk taking to be enabled, it is essential for these organisations to develop internally without fear of failure, which is an inevitable part of the innovation process (Mazzucato and Penna, 2015). An important and open question, which we did not seek to address in this paper, might be whether the appetite for risk is affected by the source of funds. For example, whether the funds come directly from the treasury (as in BNDES's most recent history), from bond issuing on capital markets (as in KfW), from savers' deposits (as in the case of other SIBs such as Italy's public bank Cassa Depositi and Prestiti) or from workers' contributions (as in the case of BNDES's FAT fund).

Not all SIBs play a mission-oriented role, or are equally efficient and effective at performing it. Some authors (such as Gutierrez et al., 2011; Schapiro, 2012) have argued that the establishment of a well-defined mandate is key for the effectiveness of a SIB. For Gutierrez et al. (2011), a clearly defined mandate is one that assigns to SIBs a 'gap filling' (p. 12) role, such as closing the funding gap for SMEs; in other words, a mandate justified by a market failure. While we agree that a mandate is crucial, we strongly disagree that it must be guided by the market failure approach. Our argument is that these mandates need to target not a market failure but a societal challenge; they should be mission-oriented mandates, as is becoming the case with KfW and BNDES. Given the broad array of societal challenges faced by capitalist economies - ageing, climate change, energy security, obesity, etc. mission-oriented SIBs can make a substantive contribution in the form of catalysing investments and dynamising areas for which markets do not yet exist.

We conclude this paper with the following proposition: The very institutional macro-micro structure of SIBs makes them the most appropriate type of public agency to tackle grand challenges. These challenges are also known as contemporary missions, which have the characteristics outlined in the 'Maastricht Memorandum' (see Table 1). In light of these characteristics, central funding sources (executive agencies), as for the historical missions, seem ill-positioned to promote mission-oriented investments. This creates the need for alternative sources, and we argue that SIBs, which are already fulfilling a mission-oriented role, are appropriate in this regard. As our empirical discussion has shown, the fact that these SIBs are banking institutions enables them to access the economic feasibility of projects. Moreover, SIBs have traditionally supplied long-term finance (for capital-intensive projects, for example), and patient long-term committed finance is crucial for making new 
mission-oriented (or 'challenge-led') projects economically feasible. Banking institutions are also well positioned to coordinate stakeholders (as is done by KfW's brokerage and networking actions), as part of the banking process is to establish relationships and build up a network with an array of actors (from government officials to corporate actors to consumers). The vast portfolio of funding tools that SIBs have at their disposal (equity, loans, grants, etc.) enables them to match the most appropriate finance to the project (as we have shown in the case of BNDES), whether it is incremental or radical (for example, equity or risk contracts for the radical innovation, loans to incremental innovation projects, grants to visionary R\&D). Finally, SIBs have traditionally executed their roles in coordination with governmental policies, and new missions could potentially build on this important node in the governmental network. We conclude that state investment banks represent a concrete institutional tool to help reform the financial system from within.

By placing SIBs at the centre of the investment process, countries like Germany (and to a lesser extent - until recently - Brazil) have been able to smooth the effect of speculative financial markets and economic crises, at the same time as contributing to a transition to a more sustainable, smart and inclusive type of economic development. The research agenda on the roles of SIBs require the development of alternative frameworks to the one based on market failure theory. This paper has not provided a full answer regarding how alternative frameworks to evaluate what SIBs are doing should look (see Mazzucato, 2014; Mazzucato and Penna, 2014). The development of a new evaluation framework should include an array of new indicators that may capture the dynamic outcomes of mission-oriented investments. If strategic SIBs are creating new technologies, firms, sectors and markets, this must translate into new indicators to evaluate their performance, judging them on whether markets that did not previously exist have been created. Therefore, the new mission-oriented role for SIBs calls for new indicators that help show whether these institutions are making things happen that otherwise would not. From what we saw in the empirical section, such indicators would include: (a) the proportion of investments made in traditional areas (infrastructure) and in new (innovation) areas (new technologies, new firms, new sectors); (b) sources of the funding used for investments in innovation; (c) the degree of risk incurred in specific areas (specifically, areas that are more capital-intensive and embody more technological and market risk); (d) the percentage of profits/returns from funding of traditional sectors that are reinvested in areas with future potential; (e) indicators of performance from investments in innovation and innovative enterprises (for example, new products, technologies, patents, high-skilled jobs generated); (f) types of innovation generated (incremental/radical, product/process, etc.); and ( $\mathrm{g}$ ) indicators of whether new capabilities and skills are created at the firm level, and of whether new technologies, sectors and markets are created at the micro- and macro-economic levels. We hope that this paper will stimulate future research into the relationship among finance, innovation, and mission-oriented policies, and ultimately result in the development of a new framework that can guide mission-oriented policy initiatives executed through state investment banks and also through other public funding institutions.

\section{References}

Amsden, A.H., 2001. The rise of "the rest": challenges to the West from late-industrializing economies. Oxford University Press, Oxford; New York.

Arrow, K., 1962. Economic welfare and the allocation of resources for invention, in: Nelson, R.R. (Ed.), The Rate and Direction of Inventive Activity. Princeton University Press, Princeton, NJ:, pp. 609-626.

Bastos, V., 2012. 2000-2010: uma década de apoio federal à inovação no Brasil. Revista do BNDES 19, 127-176.

Birch, D.L., Medoff, J., 1994. Gazelles, in: Solmon, L.C., \& Levenson, A.R. (Eds.), Labor markets, employment policy and job creation. Westview, Boulder, CO, pp. 159-167. 
Block, F.L., Keller, M.R., 2011. State of innovation: the U.S. government's role in technology development. Paradigm Publishers, Boulder, CO.

BNDES, 2012. Apoio à Inovação. BNDES, Rio de Janeiro.

Breznitz, D., Ornston, D., 2013. The Revolutionary Power of Peripheral Agencies Explaining Radical Policy Innovation in Finland and Israel. Comparative Political Studies 46, 1219-1245.

Cantner, U., Pyka, A., 2001. Classifying technology policy from an evolutionary perspective. Research Policy 30, 759-775.

Cavalcante, L.R., de Negri, F., 2011. Trajetória recente dos indicadores de inovação no Brasil. Texto para Discussão IPEA 1659.

Chang, H.J., 2002. Kicking Away the Ladder: Development Strategy in Historical Perspective. Anthem Press.

Cherobim, A.P.M.S., de Mendonça, A.T.B.B., Woehl, S., Nascimento, T.C., 2011. Venture Capital in Brazil: the role of the seed fund CRIATEC. Análise 22, 189-201.

Climate Policy Iniciative, 2013. The Global Landscape of Climate Finance 2013. Available at: http://climatepolicyinitiative.org/publication/global-landscape-of-climate-finance2013/ Acessed on: 19/2/2014.

Coutinho, L., Ferraz, J.C., Leal, C.F.C., Braga, J.P., 2011. Desenvolvimento com base em inovação: oportunidades para o Brasil e implicações de política. Parcerias Estratégicas 16, 125-130.

De Aghion, B.A., 1999. Development banking. Journal of Development Economics 58, 83100.

de Negri, J., Salerno, M., Castro, A., 2005. Inovações, Padrões Tecnológicos e Desempenho das Firmas Industriais Brasileiras, in: Negri, J.D., Salerno, M. (Eds.), Inovações, Padrões Tecnológicos e Desempenho das Firmas Industriais Brasileiras. IPEA, Brasília.

Department of Energy (DoE), 2012. Department of Energy: Successes of the Recovery Act. US Department of Energy, Washington, DC.

Dore, R., 2008. Financialization of the Global Economy. Industrial and Corporate Change 17, 1097-1112.

Duve, T., 2007. Financing Environmental Protection \& Energy Efficiency. KfW Institutional Presentation.

Edquist, C., Zabala-Iturriagagoitia, J.M., 2012. Public Procurement for Innovation as mission-oriented innovation policy. Research Policy 41, 1757-1769.

Enting, K., 2013. Mobilizing Private Sector Investment: KfW Case Studies and Conclusions. OECD.

Ergas, H., 1987. Does technology policy matter. Technology and global industry: Companies and nations in the world economy, 191-245.

European Commission 2011. Horizon 2020: The Framework Programme for Research and Innovation (2014-2020). Brussels: European Commission.

Ferraz, J.C., Além, A.C., Madeira, R.F., 2013. A contribuição dos bancos de desenvolvimento para o financiamento de longo prazo. Revista do BNDES 40, 5-42.

Financial Times, 2012. A bank too big to be beautiful, FT Special Reoport on the Future of Development Banls , 24/9, p. 3.

Foray, D., Mowery, D., Nelson, R.R., 2012. Public R\&D and social challenges: What lessons from mission R\&D programs? Research Policy 41, 1697-1902.

Freeman, C., 1996. The Greening of technology and models of innovation. Technological Forecasting \& Social Change 53, 27-39.

FS-UNEP/BNEF, 2013. Global Trends in Renewable Energy Investment 2013. BNEF.

George, A. and Bennett, A. (2005) Case Studies and Theory Development in the Social Sciences. Cambridge (MA): MIT Press.

Grunwald, M., 2012. The New New Deal: The Hidden Story of Change in the Obama Era. Simon and Schuster.

Gumb, G., 2012. German approaches in promoting energy efficiency: KfW best practice experience. Workshop on Energy Efficiency. 
Gutierrez, E., Rudolph, H.P., Homa, T., Blanco Beneit, E., 2011. Development banks: role and mechanisms to increase their efficiency. World Bank Policy Research Working Paper.

Haldane, A.G., 2011. The Short Long, 29th Société Universitaire Européene de Recherches Financières Colloquium: New Paradigms in Money and Finance?, Brussels.

Hensarling, J. \& McHenry, P. 2014. Failing to End Too Big to Fail: An Assessment of the Dodd-Frank Act Four Years Later. Report prepared by the Republican staff of the Committee on Financial Services, US House of Representatives. Washington, DC: US House of Representatives.

Kaminker, C., Kawanishi, O., Stewart, F., Caldecott, B., Howarth, N., 2013. Institutional Investors and Green Infrastructure Investments.

Kay, J. (2012) The Kay review of UK equity markets and long-term decision making. Available at: https://www.gov.uk/government/publications/the-kay-review-of-ukequity-markets-and-long-term-decision-making-final-report. Acessed on: 23/2/2014.

Keynes, J.M., 1926. The end of laissez-faire. Prometheus Books, London.

Keynes, J. M. 2006 [1936]. General Theory of Employment, Interest and Money, Atlantic, New Delhi.

KfW 2013. What we do - Facts and Figures 2012 - Sustainability Report 2012, Frankfurt am Main, KfW Group.

$\mathrm{KfW}, 2014 \mathrm{a}$. KfW position on financing of coal-fired power plants, 10/3/2014 ed. KfW, Frankfurt am Main.

KfW, 2014b. KfW presents itself: Structure and Mission of KfW as of September 2014, September 2014 ed. KfW, Frankfurt am Main.

Kregel, I., 2012. Trying to Serve Two Masters. After the Great Recession: The Struggle for Economic Recovery and Growth, 86.

Krippner, G. R. 2005. The financialization of the American economy. Socio-Economic Review 3, 173-208.

Lazonick, W. 2013. The Financialization of the U.S. Corporation: What has been Lost, and How it can be Regained. Seattle University Law Review 36, 857-909.

Lazonick, W., Tulum, Ö., 2011. US biopharmaceutical finance and the sustainability of the biotech business model. Research Policy 40, 1170-1187.

Louw, A., 2013. Development Banks - breaking the $\$ 100 \mathrm{bn}-\mathrm{a}-\mathrm{year}$ barrier. Bloomberg New Energy Finance, Clean Energy White Paper, Sep. 10.

Mathews, J.A., 2006. Catch-up strategies and the latecomer effect in industrial development. New Political Economy 11, 313-335.

Mattos, P.T.L., 2008. Institutions for industrial development and innovation: the state as a risk taker in Brazil. Law and the New Developmental State (LANDS) Project Report.

Mazzucato, M., 2013a. The Entrepreneurial State: Debunking the Public vs. Private Myth in Risk and Innovation. Anthem Press.

Mazzucato, M., 2013b. Financing innovation: Creative destruction vs. destructive creation. Industrial and Corporate Change 22, 851-867.

Mazzucato, M., Penna, C.C.R., 2014. Beyond Market Failures: State Investment Banks and the 'Mission-Oriented' Finance for Innovation. SPRU Working Paper Series, 2014(21). Available at:

https://www.sussex.ac.uk/webteam/gateway/file.php?name=2014-21-swpsmazzucato-and-penna.pdf\&site=25 Accessed on: 23/11/2014.

Mazzucato, M., Penna, C.C.R. (eds.) 2015. Mission-Oriented Finance for Innovation: New Ideas for Investment-Led Growth, London: Rowman \& Littlefield.

Mazzucato, M., Perez, C., 2014. Innovation as Growth Policy: the challenge for Europe. SPRU Working Paper Series 2014(13). Available at: https://www.sussex.ac.uk/webteam/gateway/file.php?name=2014-13-swpsmazzucato-perez.pdf\&site=25 Accessed on: 23/11/2014.

Minsky, H.P., 1992. The Capital Development of the Economy and the Structure of Financial Institutions. Levy Institute Working Paper Series 72. 
Minsky, H.P., Papadimitriou, D.B., Phillips, R.J. \& Wray, L.R. 1993. Community Development Banking: A Proposal to Establish a Nationwide System of Community Development Banks. Levy Institute Public Policy Brief, 3/1993.

Minsky, H. P. \& Whalen, C. 1996. Economic Insecurity and the Institutional Prerequisites for Successful Capitalism. Levy Institute Working Paper Series, 165.

Mowery, D.C., 2010. Military R\&D and innovation, in: Hall, B.H., Rosenberg, N. (Eds.), Handbook of the Economics of Innovation, pp. 1219-1256.

Mowery, D.C., 2012. Defense-related R\&D as a model for "Grand Challenges" technology policies. Research Policy 41, 1703-1715.

Mowery, D.C., Nelson, R.R., Martin, B.R., 2010. Technology policy and global warming: Why new policy models are needed (or why putting new wine in old bottles won't work). Research Policy 39, 1011-1023.

Murray, F., Stern, S., Campbell, G., MacCormack, A., 2012. Grand Innovation Prizes: A theoretical, normative, and empirical evaluation. Research Policy 41, 1779-1792.

Mussler, H., 2013. Germany's Vampire Squid. Financial World February, 28-29.

O'Sullivan, M. 2004. Finance and innovation. In: Fagerberg, J., Mowery, D.C. \& Nelson, R.R. (eds.) The Oxford Handbook of Innovation. New York: Oxford University Press.

Palmeira Filho, P.L., Pieroni, J.P., Antunes, A., Bomtempo, J.V., 2012. O desafio do financiamento à inovação farmacêutica no Brasil: a experiência do BNDES Profarma. Revista do BNDES 37, 67-90.

Papadimitriou, D.B. \& Wray, L.R. 1998. The economic contributions of Hyman Minsky: varieties of capitalism and institutional reform. Review of Political Economy, 10, 199_ 225.

Peneder, M., 2008. The problem of private under-investment in innovation: A policy mind map. Technovation 28, 518-530.

Perez, C., 2002. Technological revolutions and financial capital: the dynamics of bubbles and golden ages. E. Elgar Pub., Cheltenham, UK; Northampton, MA.

Polanyi, K., 2001 [1944]. The great transformation: the political and economic origins of our time, 2nd Beacon Paperback ed. Beacon Press, Boston, MA.

Ramundo, J., 2013. Challenges of financing innovation. Presentation for the Minds' Conference on Financial Institutions for Innovation and Development June 28.

Reinert, E.S., 1999. The role of the state in economic growth. Journal of Economic Studies $26,268-326$.

Sampat, B.N., 2012. Mission-oriented biomedical research at the NIH. Research Policy 41, $1729-1741$.

Schapiro, M.G., 2012. Rediscovering the Developmental Path? Development Bank, Law, and Innovation Financing in the Brazilian Economy. SSRN Working Paper.

Schumpeter, J.A., 1934 [1912]. The Theory of economic development: an inquiry into profits, capital, credit, interest, and the business cycle. Harvard University Press, Cambridge, Mass.

Soete, L., Arundel, A., 1993. An Integrated Approach to European Innovation and Technology Diffusion Policy: A Maastricht Memorandum. Commission of the European Communities, SPRINT Programme, Luxembourg.

Veblen, T. 1904. The theory of business enterprise, New York, C. Scribner's Sons.

Veugelers, R., 2012. Which policy instruments to induce clean innovating? Research Policy $41,1770-1778$.

Wheatley, J., 2013. Brazil's BNDES: crowding out, not crowding in, Financial Times.

Wray, L. R. 2012. The Great Crash of 2007 Viewed through the Perspective of Veblen's Theory of the Business Enterprise, Keynes's Monetary Theory of Production and Minsky's Financial Instability Hypothesis. In Reinert, E.S. \& Viano, F.L. (eds.) Thorstein Veblen: Economics for an Age of Crises. London: Anthem Press.

Wright, B.D., 2012. Grand missions of agricultural innovation. Research Policy 41, 17161728.

Yin, R. K. (2003) Case Study Research: Design and Methods. Third ed. Thousand Oaks (CA): Sage Publications. 
Zanatta, R., 2012. Criatec I ao Criatec II: o que mudou? 


\section{Recent papers in the SPRU Working Paper Series:}

SWPS 2015-17. Anders Bornhäl, Sven-Olov Daunfeldt, Niklas Rudholm. May 2015. Employment Protection Legislation and Firm Growth: Evidence from a Natural Experiment.

SWPS 2015-18. Phil Johnstone, Andy Stirling. June 2015. Comparing Nuclear Power Trajectories in Germany And the UK: From 'Regimes' to 'Democracies' in Sociotechnical Transitions and Discontinuities.

SWPS 2015-19. Maria Savona. July 2015. Global Structural Change And Value Chains In Services. A Reappraisal.

SWPS 2015-20. Javier Lopez Gonzalez, Valentina Meliciani, Maria Savona. July 2015. When Linder Meets Hirschman: Inter-Industry Linkages and Global Value Chains in Business Services.

SWPS 2015-21.J. Sylvan Katz. July 2015. What is a Complex Innovation System?

SWPS 2015-22. Friedemann Polzin, Paschen von Flotow, Laurens Klerkx. August 2015. Accelerating the Cleantech Revolution: Exploring the Financial Mobilisation Functions of Institutional Innovation Intermediaries.

SWPS 2015-23. Tommaso Ciarli, Alex Coad, Ismael Rafols. August 2015. Quantitative Analysis of Technology Futures: A review of Techniques, Uses and Characteristics.

SWPS 2015-24. Lee Stapleton. August 2015. Do Academics Doubt Their Own Research?

SWPS 2015-25. Mariana Mazzucato. September 2015. From Market Fixing to MarketCreating: A New Framework for Economic Policy.

Suggested citation:

Caetano Penna, Mariana Mazzucato (2015). The Rise of Mission-Oriented State Investment Banks: The Cases of Germany's KfW and Brazil's BNDES. SPRU Working Paper Series (SWPS), 2015-26: 1-33. ISSN 2057-6668. Available at www.sussex.ac.uk/spru/swps2015-26

SPRU - Science Policy Research Unit

University of Sussex

Falmer, Brighton, BN1 9SL,United Kingdom

www.sussex.ac.uk/spru

Twitter:@SPRU

SWPS: $\underline{w w w . s u s s e x . a c . u k / s p r u / r e s e a r c h / s w p s}$ 